\title{
Moonlighting of mitotic regulators in cilium disassembly
}

\author{
Cenna Doornbos ${ }^{1,2}\left(\mathbb{0} \cdot\right.$ Ronald Roepman $^{1,2}(\mathbb{0}$
}

Received: 23 October 2020 / Revised: 3 March 2021 / Accepted: 27 March 2021 / Published online: 15 April 2021

(c) The Author(s) 2021

\begin{abstract}
Correct timing of cellular processes is essential during embryological development and to maintain the balance between healthy proliferation and tumour formation. Assembly and disassembly of the primary cilium, the cell's sensory signalling organelle, are linked to cell cycle timing in the same manner as spindle pole assembly and chromosome segregation. Mitotic processes, ciliary assembly, and ciliary disassembly depend on the centrioles as microtubule-organizing centres (MTOC) to regulate polymerizing and depolymerizing microtubules. Subsequently, other functional protein modules are gathered to potentiate specific protein-protein interactions. In this review, we show that a significant subset of key mitotic regulator proteins is moonlighting at the cilium, among which PLK1, AURKA, CDC20, and their regulators. Although ciliary assembly defects are linked to a variety of ciliopathies, ciliary disassembly defects are more often linked to brain development and tumour formation. Acquiring a better understanding of the overlap in regulators of ciliary disassembly and mitosis is essential in finding therapeutic targets for the different diseases and types of tumours associated with these regulators.
\end{abstract}

Keywords Cilia · Cilium resorption · WNT Cell cycle regulators · Centrioles · Tumour development

$\begin{array}{ll}\text { Abbreviations } \\ \text { +TIP } & \text { Plus-end tracking tip protein complex } \\ \text { APC/C } & \text { Anaphase promoting complex/cyclosome } \\ \text { IFTA } & \text { Intraflagellar transport, retrograde } \\ \text { IFTB } & \text { Intraflagellar transport, anterograde } \\ \text { K-fibres } & \text { Kinetochore fibres } \\ \text { KMN } & \text { KNL1/MIS12/NDC80 complex } \\ \text { MCC } & \text { Mitotic checkpoint complex } \\ \text { MT } & \text { Microtubule } \\ \text { MTOC } & \text { Microtubule-organizing centre } \\ \text { NPC } & \text { Nuclear pore complex } \\ \text { NUP } & \text { Nuclear pore } \\ \text { PCM } & \text { Pericentriolar matrix } \\ \text { PTM } & \text { Post-translational modification } \\ \text { RZZ } & \text { KNTC1 (also known as ROD)-ZWILCH-ZW10 } \\ & \text { complex } \\ \text { SHH } & \text { Sonic hedgehog signalling pathway } \\ \text { TZ } & \text { (Ciliary) transition zone }\end{array}$

Ronald Roepman

Ronald.Roepman@radboudumc.nl

1 Department of Human Genetics, Radboud University Medical Center, Nijmegen, The Netherlands

2 Radboud Institute for Molecular Life Sciences, Radboud University Medical Center, Nijmegen, The Netherlands
UPS Ubiquitin-proteasome system

WNT Wingless and Int-1 signalling pathway

\section{Introduction}

Primary cilia are small organelles protruding from the plasma membrane. Their immobility distinguishes them from their motile counterparts, that have a clear function in extracellular fluid propulsion. Primary cilia are conserved across a variety of species and are present on almost every mammalian cell. These cilia have evolved into cellular signalling hubs by harbouring components of critical cell signalling pathways, such as the 'Wingless and Int-1' (WNT) signalling pathway [1, 2], 'Sonic hedgehog' (SHH) [3, 4], and autophagy $[5,6]$. The exact ciliary signalling functions of the primary cilia vary widely and depend on the developmental stage and cell type. Due to their near-ubiquitous prevalence, dysfunction of the cilia can disturb the formation and functioning of a variety of organs, and therefore, is linked to a wide, overlapping spectrum of hereditary disorders denominated "ciliopathies" [7].

Next to its general role as a cellular signalling hub, a more specific function of cilia in cell cycle regulation has become increasingly pronounced. Several studies suggest a link between cilia, tumour formation, and in some cases, mosaic 
variegated aneuploidy (MVA) syndrome [8-11]. This link is best explained by the important double role of the centrosomal centrioles in both segregation of the sister chromatids during cell division and in ciliogenesis during the G0/G1 phase of the cells cycle (Fig. 1a). As these roles of the centrioles are mutually exclusive, it requires the assembly and disassembly of the cilia each round of the cell cycle (Fig. 1b). The terms centriole, centrosome, microtubule-organizing centre (MTOC), spindle pole and basal body are often used intertwined, but they do not always refer to the same structures (Fig. 1c). After facilitating segregation of the nuclear material during $\mathrm{M}$ phase, the centrioles migrate towards the plasma membrane. Here, the mother centriole docks to the plasma membrane using the distal appendages and drive the accumulation of ciliogenesis-specific proteins towards the pericentriolar matrix (PCM) to form the basal body, from
A

M phase
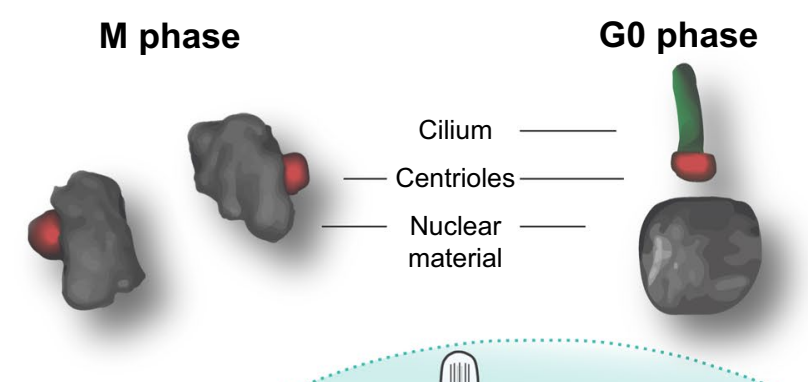

B
C

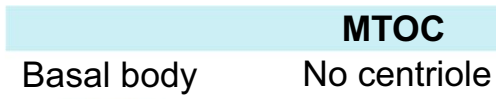

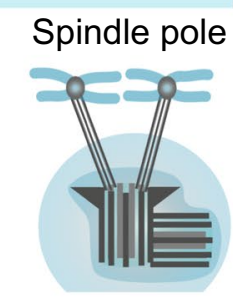
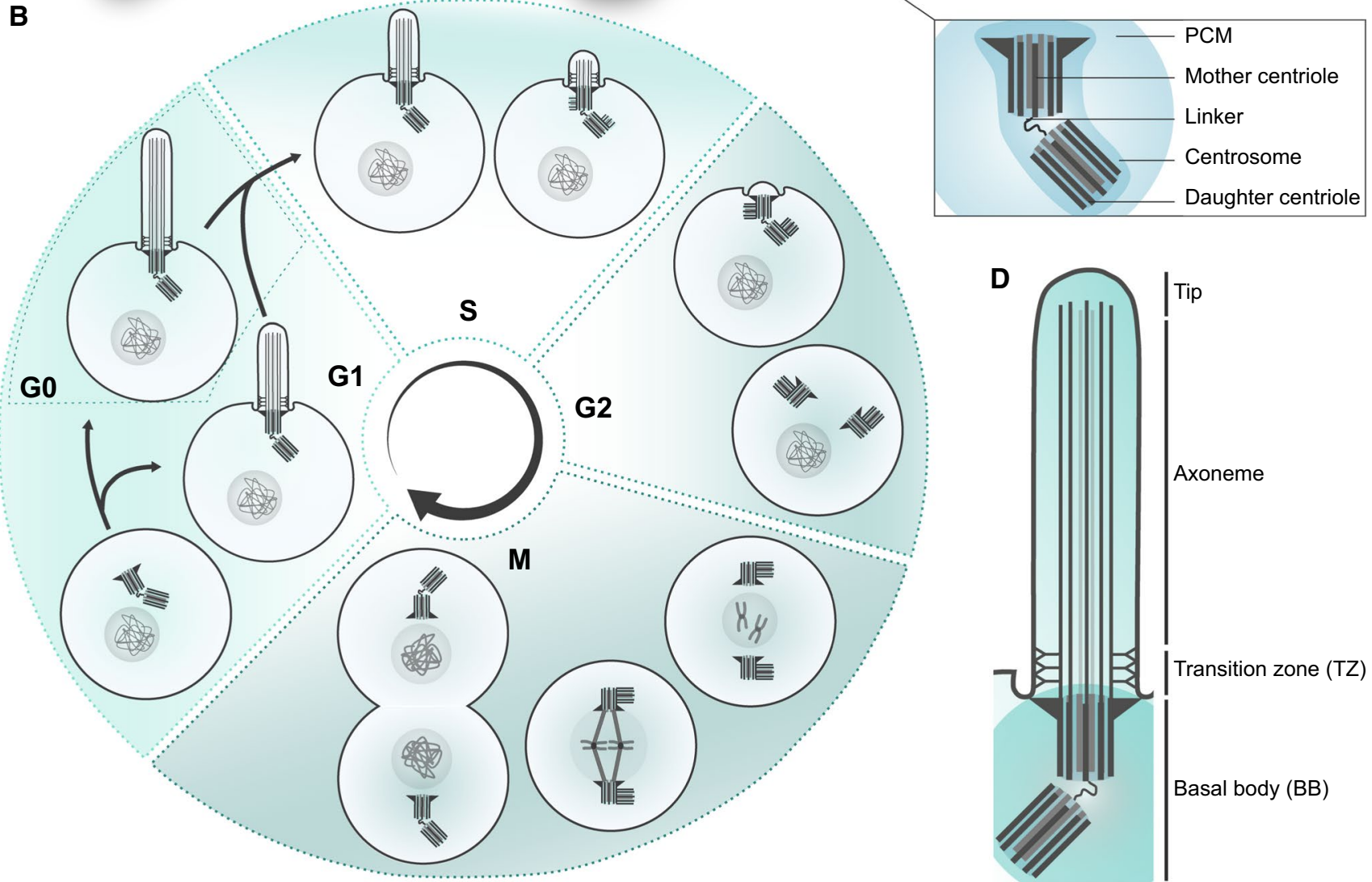

Fig. 1 Cilia and ciliation cycle. a Graphic representation of the centrioles. During mitosis ( $M$ phase) the centrioles form the spindle poles to separate the nuclear material. In quiescence (G0 phase) the centrioles (red) are positioned at the base of the cilium (green). b The cilia assemble every cell cycle in G0/G1 phase and disassemble during S/G2 phase, during which the centrioles are positioned at the ciliary base. After detachment from the plasma membrane, the linker between the mother and daughter centriole dissolves, allowing the two centrioles to move towards the nucleus to form the spindle poles. Each mother centriole forms a new daughter centriole during the next cycle. $\mathbf{c}$ The centrosomes, displaying two structurally different centri- oles surrounded by the pericentriolar material (PCM), act as the main MTOC both during spindle pole formation and ciliogenesis. Nonetheless, an MTOC can also arise without a centrosome [174]. The spindle pole and basal body refer to the centrosome as an MTOC with the pericentriolar material, but either contain proteins specific to the cell cycle, or ciliogenesis. The centrosomes gather different complexes for these specific functions, enriching the PCM for different sets of proteins, and making it more likely for interacting proteins to bind at the right phase of the cell cycle. $\mathbf{d}$ Schematic representation of the cilia and the ciliary regions that can be distinguished 
which the cilium extends $[12,13]$. When the cilia are present at the cell membrane, the centrioles cannot migrate back to the nucleus to facilitate mitosis, therefore, cell cycle re-entry requires the release of the centrioles from the membrane to enable reconstruction of the mitotic spindle poles.

The primary cilium is a highly organized organelle (Fig. 1d) [14], and ciliary assembly and disassembly are complex, well-timed mechanisms that regulate the formation and breakdown of each ciliary component. Even though the basal body forms the root of the cilium, it also functions as a protein recruitment centre. Several mechanisms cooperate to deliver proteins to the ciliary base in a tightly regulated fashion. The ciliary membrane has a different composition than the plasma membrane and this is regulated at the ciliary pocket and transition zone (TZ) $[15,16]$. The membrane of the cilium is enriched for signalling molecules and ciliumspecific membrane regulators. Other proteins that are not membrane-associated can be recruited from the cytoplasm to the centriolar satellites $[17,18]$. To assure correct protein trafficking, a gating module is localized at the TZ just above the basal bodies $[19,20]$. Active transport along the microtubules (MTs) that make up the ciliary axoneme is regulated by two sets of 'Intraflagellar transport' (IFT) proteins: IFTA for retrograde transport to the ciliary base using dynein motor proteins and IFTB for anterograde transport to the tip of the cilia using kinesin motor proteins [21]. This strict regulation is also seen in ciliary maintenance during G0-G1 phase, by a constant balance between ciliary assembly and disassembly [22].

\section{Ciliary disassembly}

Cilia can disassemble by either cilium resorption or cilium excision (Fig. 2a). During resorption, the primary cilium is broken down gradually at variating velocities and all components are resorbed by the cell [23-25]. On the other hand, during excision the membrane of the cilium is pinched to shed part of the cilium [25]. The latter is also called whole cilium shedding and is not to be confused with ciliary vesicle shedding, in which small membranous vesicles are released extracellularly from the cilium [26-28]. Ciliary excision was previously reported in Chlamydomonas reinhardtii in which stress allowed to shear off the whole cilium at the TZ $[29,30]$. This mechanism can be induced through an acidity shock or by Dibucaine treatment, leaving a cilium-enriched fraction after centrifugation of the growth medium [30-32]. More recent reports have shown that this mechanism of cilium excision is also conserved in mammalian cells [25]. Although the role of primary cilium excision in mammalian cells requires further exploration, the significance of resorption as a mechanism of ciliary disassembly is well established and it has been shown that cilium resorption is essential for cell survival in cycling cells [33].

\section{The core axis in ciliary resorption is stimulated through WNT}

For a protein to be considered a ciliary resorption protein, it has to been proven that it influences ciliary length during ciliary disassembly, while it is not involved in ciliary excision or budding. The core players in ciliary resorption are represented by the NEDD9/AURKA/HDAC6 axis, located at the base of the cilia (Fig. 2b). HDAC6 destabilizes ciliary MTs through deacetylation [34, 35]. HDAC6 localizes the MTOC organizing protein AURKA to the basal body, where it is stabilized by NEDD9 (previously known as HEF1) $[23,36]$. Since most proteins discussed here have multiple names, all proteins names, alternative names and their corresponding IDs are summarized in Electronic Supplementary Material-Table 1. NEDD9 stabilization prevents ubiquitin-proteasome system (UPS)-mediated degradation of AURKA [37]. In turn, AURKA promotes HDAC6-mediated axoneme destabilization, functioning as a feedforward loop in ciliary disassembly.

The NEDD9/AURKA/HDAC6 axis is promoted through multiple pathways, among which mitochondrial stimulation through CALM1 [38, 39]. Another example is autophagy, since serum-starvation is often used in cell culture to induce cell cycle arrest and stimulate cilium formation [40]. On the other hand, serum resupplementation is associated with MTOR activation, ciliary disassembly and cell cycle reentry. AURKA activation is also mediated by PCM1, which recruits PLK1 to the basal body during ciliary disassembly [41]. Furthermore, PIFO-dependent AURKA activation promotes ciliary disassembly and is linked to left-right symmetry patterning $[42,43]$. Last, the best-described pathway to stimulate ciliary resorption is WNT signalling. WNT signalling promotes cell cycle division and is essential in embryonic development, but also stimulates the NEDD9/AURKA/ HDAC6 axis [44]. Extracellular WNT5A activates FZD1 on the cell membrane to promote DVL2 signalling [45]. In turn, DVL2 promotes PLK1-dependent phosphorylation of AURKA, resulting in more potent deacetylation by HDAC6. Furthermore, PLK1 enhances the MT depolymerisation through kinesin motor protein KIF2A in ciliary disassembly [46]. Thus far, one potentially pathogenic KIF2A mutation has been found in patients with microcephaly [47].

There are several WNT5A mutations that are linked to Robinow syndrome. Robinow has previously been indicated as a possible ciliopathy due to the overlap in symptoms compared to skeletal ciliopathies [48]. It would, therefore, be interesting to determine what the molecular influence is of these WNT5A mutations on ciliary disassembly and function. Another hypothesized ciliopathy causing mutation is 
A
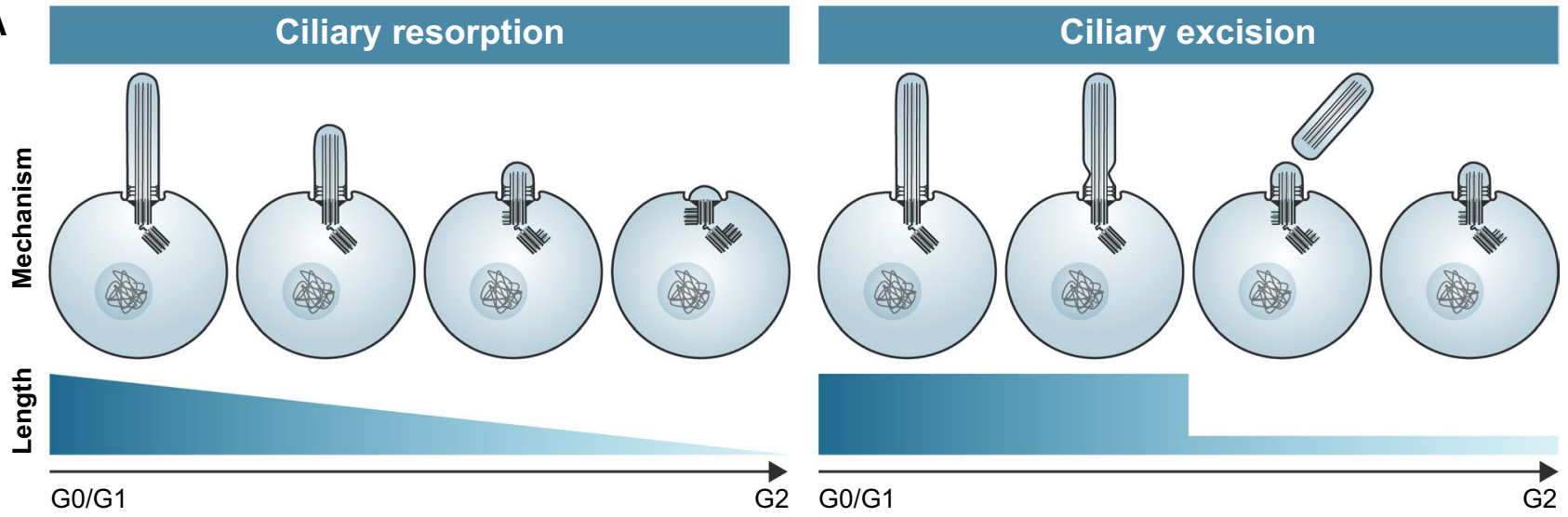

B

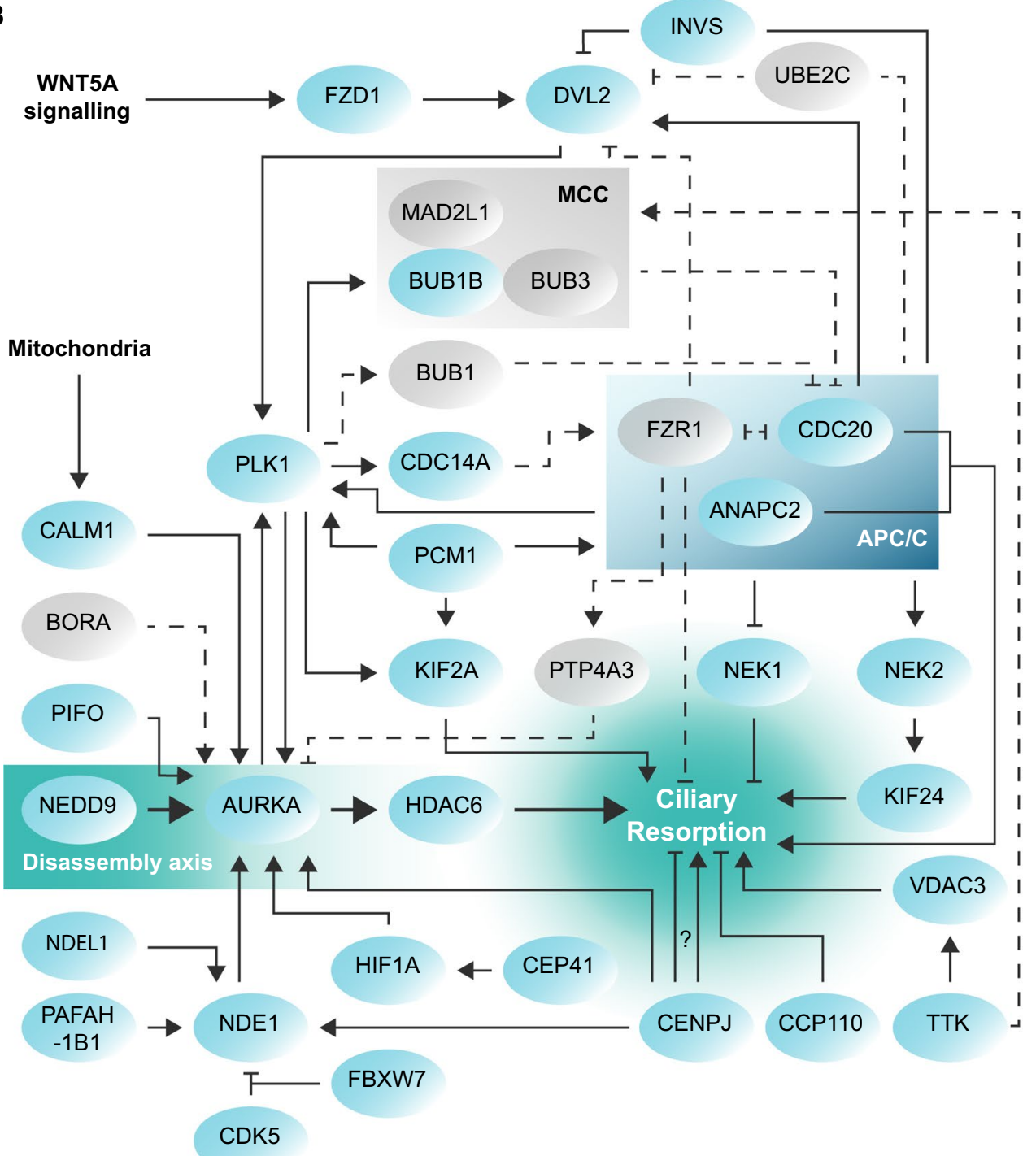

the premature stop mutation $282 \mathrm{~A}>\mathrm{T}$ in HDAC6, since it causes chondrodysplasia, brachydactyly, hydrocephaly and microphthalmia (Table 1) [49]. Furthermore, as part of the core disassembly axis, a tight regulation of NEDD9 and
AURKA is essential. For NEDD9, there are no known pathogenic mutations, however, high protein levels are associated with breast cancer [37]. High protein levels of ARUKA are associated with several types of tumours and poor survival 
४Fig. 2 Ciliary disassembly mechanism. a A schematic representation of ciliary resorption versus ciliary excision. b The core axis of ciliary disassembly is regulated through the NEDD9/AURKA/HDAC6 pathway that drives ciliary resorption. This axis can be stimulated by the mitochondria, extracellular WNT signalling and cell cycle regulators. The criteria for a protein to be considered a ciliary resorption protein, and to be included in this schematic overview, the protein has to influence ciliary length during disassembly, but is not involved in ciliary excision or budding. All of these proteins with a confirmed role in ciliary resorption are shown in blue. In addition to these, proteins shown in grey and with dotted lines indicate known interactors of these resorption proteins, but which have not yet been investigated in the context of ciliary resorption specifically. PLK1 both stimulates and inhibits ciliary resorption by phosphorylation of a wide variety of targets. The APC/C stimulates ciliary resorption when activated by CDC20. For CENPJ, the exact role in ciliary resorption remains elusive

rates [50, 51]. Overall, AURKA is considered the key link between ciliary disassembly and tumour development, which has recently been reviewed in depth [52].

\section{The cell cycle complex APC/C plays a key role in ciliary resorption}

Next to its role in anaphase, the E3 ubiquitin ligase APC/C is also involved in ciliary disassembly. Its complex member ANAPC 2 and APC/C co-activator CDC20 promote ciliary disassembly, potentially by targeting ciliary components for UPS-mediated degradation [53]. The mitotic checkpoint complex (MCC) cell cycle regulator, consisting of BUB1B, BUB3 and MAD2L1, is thought to competitively bind CDC20, to prevent APC/C-CDC20 complex formation during G0/G1 phase [54]. BUB1B has been shown to function as a negative regulator of ciliary disassembly [54]. Next to CDC20, the APC/C can also be activated through FZR1 (previously known as CDH1), to target a different set of proteins. Furthermore, CDC20 knockdown and FZR1 overexpression resulted in reduced DVL2 levels [54] and ANAPC2 is required for cilia polarity through DVL2-WNT signalling [55]. Together these data suggest that APC/C-CDC20 is a disassembly promoter, while APC/C-FZR1 might inhibit ciliary disassembly.

The role of PLK1 in this process remains unclear. PLK1 depletion results in decreased CDC14A-dependent dephosphorylation of FZR1 [56] and CDC14A is a positive regulator of ciliogenesis [57]. Furthermore, PLK1 activity is promoted by the APC/C, which both support the idea that FZR1 might be a ciliary resorption inhibitor. On the other hand, during $\mathrm{M}$ phase, APC/C-CDC20 targets PLK1 and BUB1B for proteasomal degradation upon correct kinetochore attachment, to allow mitotic exit [58, 59]. Mutations in BUB1B are associated with MVA, colorectal cancer (CRC), and premature chromatid separation (PCS), but there are no known pathogenic patient mutations for PLK1 [60, 61]. Together, these data indicate that the exact mechanism of PLK1 and APC/C regulation is dependent on the specific spatiotemporal conditions and that their role might differ if the cell is in mitosis or performing ciliary disassembly.

The APC/C regulates its function in ciliary disassembly through multiple targets. One group is the family of "never in mitosis gene A' '(NIMA) related kinase' (NEK) family of kinases, that are thought to function as cell cycle and checkpoint control proteins [62]. NEK1 promotes centrosome stability during ciliogenesis and is associated with polycystic kidney disease (PKD) [63], and skeletal ciliopathies [64]. NEK1 is linked to ciliary tubulin organization through CEP104, while APC/C-mediated degradation of NEK1 is required for ciliary resorption $[53,65,66]$. In addition, NEK2-mediated activation of KIF24 is required for ciliary disassembly [67] and incorrect functioning of NEK2 is related to the ciliopathy retinitis pigmentosa (RP) [68]. Overall, the family of NEK proteins is associated with different types of tumours [62].

Next to the NEK proteins, the APC/C can influence ciliary resorption through AURKA activation or degradation. In turn, this influences HDAC6-regulated ciliary disassembly through INVS, which marks the ciliary INVS/NPHP3 compartment, located just above the TZ in the cilium. Mutations in INVS cause the ciliopathy Nephronophthisis (NPHP) type $2[69,70]$. It binds ANAPC2 to promote DVL2 degradation and, as a consequence, inhibits AURKA phosphorylation by PLK1 [71]. In mature human retinal pigment epithelium (RPE) cells it has been shown that this mechanism is used in fully differentiated cells to inhibit ciliary disassembly by recruiting INVS to the base of the cilium [72]. Interestingly, INVS also binds directly to yet another NEK protein family member, NEK8, recruiting it to the ciliary INVS/NPHP3 compartment [73]. This recruitment requires hydroxylation of INVS and ANKS6 by HIF1AN [74], and mutations in NEK8 underly the renal ciliopathy NPHP type 9 . NEK8 is important for cell cycle regulation through the Hippo signalling pathway, and in turn, the Hippo and WNT pathways closely interact to regulate gene transcription $[75,76]$. Nonetheless, it has not yet been investigated if NEK8 is also a target of direct APC/C-mediated degradation, like NEK1. In conclusion, the $\mathrm{APC} / \mathrm{C}$ has many interactors to regulate the cell cycle and ciliary resorption, but whether it is a ciliary resorption promotor or repressor might depend on the co-activator that is bound.

\section{Centrosomal proteins are involved in ciliogenesis, ciliary resorption and ciliary excision}

The centrosomal core proteins travel along with the centrioles from the spindle poles in $\mathrm{M}$ phase to the ciliary base in G1/S phase. It has been shown that the depletion of centrosome-associated proteins, among which PCM1, tubulin, and NEK2, results in a decrease in ciliogenesis [77]. In this 
Table 1 Ciliary resorption regulators and related diseases

\begin{tabular}{|c|c|c|c|}
\hline Name & OMIM disease & $\begin{array}{l}\text { Genetic vari- } \\
\text { ants (patho- } \\
\text { genic) }\end{array}$ & $\begin{array}{l}\text { Resorp- } \\
\text { tion } \\
\text { regulator }\end{array}$ \\
\hline ANAPC2 & - & $3(0)$ & $\uparrow$ \\
\hline AURKA & CRC (MIM 114500) & $3(2)$ & $\uparrow$ \\
\hline BUB1B & $\begin{array}{l}\text { MVA (MIM 257300) } \\
\text { PCS (176430) } \\
\text { CRC (MIM 114500) }\end{array}$ & $234(20)$ & $\downarrow$ \\
\hline CALM1 & $\begin{array}{l}\text { LQT (MIM 616247) } \\
\text { CPVT (MIM 614916) }\end{array}$ & $45(14)$ & $\uparrow$ \\
\hline CCP110 & - & $10(0)$ & $\downarrow$ \\
\hline CDC14A & DFNB (MIM 608653) & $37(11)$ & $\downarrow$ \\
\hline $\mathrm{CDC} 20$ & - & $2(0)$ & $\uparrow$ \\
\hline CDK5 & LIS (MIM 616342) & $9(1)$ & $\downarrow$ \\
\hline CENPJ & $\begin{array}{l}\text { MCPH (MIM 608393) } \\
\text { SCKL (MIM 613676) }\end{array}$ & $149(44)$ & $\uparrow \downarrow ?$ \\
\hline CEP41 & JBTS (MIM 614464) & $182(15)$ & $\uparrow$ \\
\hline DVL2 & - & $5(0)$ & $\uparrow$ \\
\hline FBXW7 & - & $31(14)$ & $\downarrow$ \\
\hline FZD1 & - & $2(0)$ & $\uparrow$ \\
\hline HDAC6 & Ciliopathy $^{1}$ (MIM 300863) & $33(1)$ & $\uparrow$ \\
\hline HIF1A & - & $14(0)$ & $\uparrow$ \\
\hline INVS & NPHP (MIM 602088) & $239(45)$ & $\downarrow$ \\
\hline KIF24 & - & $11(0)$ & $\uparrow$ \\
\hline KIF2A & CDCBM (MIM 615411) & $75(7)$ & $\uparrow$ \\
\hline NDE1 & $\begin{array}{l}\text { MHAC (MIM 605013) } \\
\text { LIS (MIM 614019) }\end{array}$ & $97(17)$ & $\uparrow$ \\
\hline NDEL1 & - & $0(0)$ & $\uparrow$ \\
\hline NEDD9 & - & $3(0)$ & $\uparrow$ \\
\hline NEK1 & $\begin{array}{l}\text { SRTD/SRPS } \\
\text { (MIM263520) } \\
\text { ALS (MIM 617892) }\end{array}$ & $202(47)$ & $\downarrow$ \\
\hline NEK2 & RP (MIM 615565) & $11(1)$ & $\uparrow$ \\
\hline PAFAH1B1 & LIS (MIM 607432) & 257 (124) & $\uparrow$ \\
\hline PCM1 & - & $20(0)$ & $\uparrow$ \\
\hline PIFO & - & $0(0)$ & $\uparrow$ \\
\hline PLK1 & - & $1(0)$ & $\uparrow \downarrow$ \\
\hline TTK & - & $6(1)$ & $\uparrow$ \\
\hline VDAC3 & - & $0(0)$ & $\uparrow$ \\
\hline WNT5A & DRS (MIM 180700) & $113(11)$ & $\uparrow$ \\
\hline
\end{tabular}

An overview of all validated ciliary resorption proteins, as indicated in blue in Fig. 2b, and weather these positively ( $\uparrow$ ) or negatively ( $\downarrow$ ) regulate ciliary resorption. For a protein to be included here as a ciliary resorption regulator, it has to meet the criteria that it influence ciliary length during ciliary disassembly, while it is not involved in ciliary excision or budding. The genetic variants indicate the total number of ClinVar genetic variants affecting only this gene (excluding multigene insertions, deletions and copy number variants). Between () is the number of these variants that are indicated as 'Likely pathogenic', 'Pathogenic', 'Risk factor' or 'Conflicting interpretations'. For CENPJ, there are conflicting reports whether it is a resorption promotor or repressor.

$A L S$ amyotrophic lateral sclerosis, $C D C B M$ cortical dysplasia, complex, with other brain malformations, $C P V T$ ventricular tachycardia,
Table 1 (continued)

catecholaminergic polymorphic, $C R C$ colorectal cancer, $D F N B$ deafness, with or without immotile sperm, DRS robinow, JBTS Joubert syndrome, LIS lissencephaly, LQT long QT syndrome, $M C P H$ microcephaly, $M H A C$ microhydranencephaly, $M V A$ mosaic variegated aneuploidy syndrome, NPHP nephronophthisis, $P C S$ premature chromatid separation, $R P$ retinitis pigmentosa, $S C K L$ Seckel syndrome, $S R P S$ short-rib polydactyly syndrome, $S R T D$ short-rib thoracic dysplasia

${ }^{1}$ The referred mutation in HDAC6 might cause a ciliopathy, since patients present with common ciliopathy symptoms; chondrodysplasia with platyspondyly, distinctive brachydactyly, hydrocephaly, and microphthalmia.

process the loss of centrosome integrity results in $\mathrm{G} 1$ to S phase cell cycle arrest through MAPK14 (p38 $)$, TP53 and CDKN1A (p21) cell cycle regulators [77], possibly by disruption of CEP131, PCM1 and CEP290 localization in the centriolar satellites [78]. PCM1 seems to be essential for both ciliogenesis and ciliary disassembly, most likely through its role in the recruitment of proteins to the basal body and centriolar satellites. On the other hand, centrosomal protein CEP41 blocks HIF1A UPS-mediated degradation and in turn, HIF1A stimulates AURKA phosphorylation, which promotes ciliary resorption [79]. Interestingly, HIF1AN is, next to its role in NEK8 localization, a direct inhibitor of some HIF1A interactions under normoxia conditions [80], making it an interesting target to study with regards to ciliary resorption and cellular oxygen-sensing. Another centrosomal protein, CENPJ (also known as CPAP or SAS4) has opposing roles during ciliary disassembly and mitosis, which seems to be a characteristic for disassemblyrelated proteins.

CENPJ has been indicated to promote ciliary resorption and is essential for maintenance of the neural progenitor pool by forming a scaffold for NDE1, AURKA and OFD1 [81]. In contrast, others have reported that it promotes centriole elongation and is required for centriole duplication in late mitosis $[82,83]$. This led to the opposing finding that CENPJ is a promoter of ciliogenesis and its expression decreased upon the induction of ciliary disassembly, which was not seen for disassembly proteins AURKA, PLK1 and NEK2 [84]. CENPJ is associated with Seckel syndrome (SCKL) and Microcephaly (MCPH) $[85,86]$. The precise function of CENPJ in ciliary resorption might be dependent on its interacting proteins at the centrosomes.

CCP110 (also known as CEP110) has been shown to supress cilium assembly in conjunction with CEP97 by capping the mother centriole [87], and by association with a complex of other centrosomal proteins, among which CEP290 (NPHP6), RAB8A, CEP104, and CENPJ [88-92]. In turn, CEP290, NPHP4, RPGRIP1L (NPHP8), TMEM107 and TMEM216 have been indicated in ciliary excision [93]. Mutations in CEP290 cause a variety of ciliopathies, including 'Joubert syndrome' (JBTS) [94], 'Leber congenital 
amaurosis' (LCA) [95] and 'Meckel syndrome' (MKS) [96]. Furthermore, RPGRIP1L [97, 98], TMEM107 [99, 100] and TMEM216 [101, 102] malfunctioning are also associated to JBTS and MKS among others, while mutations in NPHP4 $[103,104]$ are associated with NPHP and 'Senior-Loken syndrome' (SLS) ciliopathies. Overall, centrosomal proteins seem to have a role in ciliogenesis, ciliary resorption and ciliary excision and are associated with a range of ciliopathies, while other ciliary resorption proteins are more often associated with microcephaly and tumour formation.

In summary, ciliary resorption depends upon a complex interplay of proteins including the APC/C and WNT signalling. Many of the proteins involved in ciliary resorption also play a role in cell division and disruption of these mechanisms can lead to microcephaly and a variety of cancers. The centrosomal proteins at the base of the cilium also seem to affect ciliary resorption, but ciliary excision and ciliogenesis as well. Therefore, the mechanisms involved in cilium resorption might be different from the ones involved in ciliary excision, which is underpinned by the fact that ciliary excision proteins are associated with a variety of ciliopathies, even though ciliary resorption proteins are more often associated with tumour formation and microcephaly. The latter might be explained by the double role of many ciliary resorption proteins in mitosis. Nonetheless, we do not fully understand how these proteins specifically disturb brain formation during embryology rather than affecting all mitotic process.

\section{Mitotic structures: kinetochores and spindle poles}

After ciliary disassembly, the centrioles migrate back to the nucleus, where they behave again as the main MTOC by nucleating an assembly of MT-polymerizing proteins that form the spindle poles. The plus-ends of the MTs are bound to the kinetochore with the help of the fibrous corona. The kinetochore consists of three layers: the corona, the outer kinetochore and the inner kinetochore (Fig. 3a). Kinetochore function and architecture have been reviewed in detail [105-109]. In summary, the corona is required for the correct positioning of the chromosomes towards the equatorial plane by binding of the MTs that extend from the MTOC. Since it is more likely to bind an MT at the side, rather than at the end, the corona provides a lateral to end-on conversion with the help of motor proteins [110]. CENPF recruits the NDE1/NDEL1/PAFAH1B1 (also known as LIS1) dynein motor complex to the kinetochore [111]. Both the minusend-directed motor protein dynein and the plus-end-directed CENPE protein are required for correct localization of the kinetochores at the MT plus-ends [112, 113].
The kinetochores are aligned on the equatorial plane in bi-orientation to assure that each sister chromatid is attached to the opposite spindle pole. BUB1 recruits the KNTC1 (also known as ROD)-ZWILCH-ZW10 (RZZ) complex and BUB1B proteins to the kinetochores for the regulation of MT embedding and chromosome segregation [114]. Chromosome segregation and the onset of anaphase are strictly inhibited by the spindle poles until each kinetochore is attached to MTs [115]. Upon correct attachment of all kinetochores, $\mathrm{CDC} 20$ activates the APC/C to polyubiquitinate PTTG1 (Securin), marking it for UPS-mediated degradation. In turn, PTTG1 can no longer inhibit ESPL1 (Separin), which cleaves the Cohesin ring complex that keeps the two sister chromatids together. This precise regulation is essential, since chromosome missegregation is linked to MVA and tumour formation $[60,61]$. When the kinetochore is positioned end-on, the KNL1/MIS12/NDC80 (KMN)-complex embeds the plus-ends of the MTs into the outer kinetochore [116]. During mitosis, the kinetochore is attached to the centrosomes with the help of the inner kinetochore centromere protein (CENP) family, of which the members are rich in DNA-binding motifs.

The link between the MTOC and the kinetochores is strengthened by the formation of kinetochore fibres (k-fibres). These fibres are formed by bundling and crosslinking of the MTs, and are required to withstand the high mechanical forces involved in chromosome segregation. Incorrect cross-linking of the MTs to form the k-fibres and mutations in depolymerising MT-tracking protein CENPF have been linked to microcephaly [117-119]. Intriguingly, this phenotype is seen in a variety of ciliopathies, among which 'Mental retardation, truncal obesity, retinal dystrophy, and micropenis' (MORM), suggesting a functional overlap of the proteins involved in k-fibre formation [120].

At the end of M phase, the kinetochores are dissociated, the MTs depolymerised, and the centrioles are released [121-123]. It is interesting to see that upon the formation of a new cilium in the next G1 phase, not only the centrioles, but also many of these kinetochore proteins play a role in ciliary assembly, disassembly, or functioning.

\section{Conservation between cell cycle and ciliary disassembly proteins}

We have briefly touched upon the double role of some cell cycle regulators in ciliary disassembly and vice versa. If we look at the structural conservation between the cilia and kinetochores, we can see that the further you go towards the outside of the kinetochores, the more proteins you will find that play a role in ciliary disassembly (Fig. 3b). 


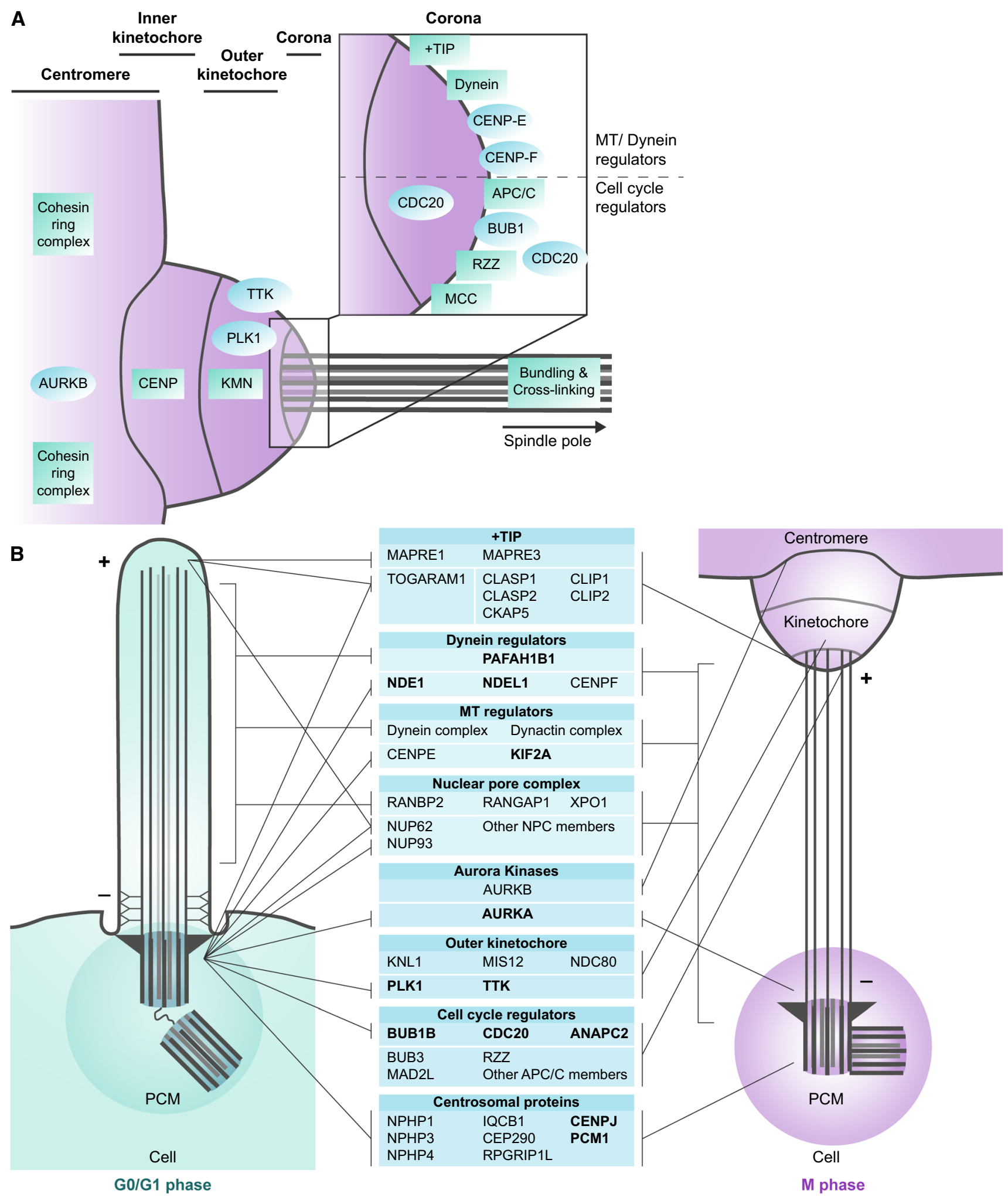


4Fig. 3 Conservation between the cilia, kinetochores and spindle poles. a Schematic representation of the kinetochore, and the key proteins present in each part of this structure. Individual proteins are indicated as circles (blue), protein complexes as squares (green). The MTs are docked onto the outer kinetochore. The corona contains many different proteins and protein complexes (inset), which either affect MT and dynein organization or cell cycle regulation. The MTs are bundled and crosslinked to withstand the high mechanical forces between the kinetochores and spindle poles prior to and upon segregation of the sister chromatids. b Many proteins and protein complexes are conserved between the cilia, kinetochores and spindle poles. Proteins that have been confirmed to play a role in ciliary resorption are marked (bold). The proteins are sorted per module and their organization in the two structures seems to be dependent on the MT organization, from minus at the bottom to plus at the top

\section{Outer kinetochore proteins, but not inner kinetochore proteins, play a role in ciliary disassembly}

Starting at the inner part, none of the inner kinetochore proteins have been detected in cilia. This is best explained by the role of the inner kinetochore proteins in binding of the kinetochore to the DNA. Since this is not required in cilia formation, the CENP family of DNA-binding proteins are not found in cilia. However, there are three CENP family members, CENPJ, CENPF, and CENPE that do have a function in ciliogenesis or ciliary disassembly. Nonetheless, these three proteins do not have DNA-binding motifs and are not localized at the inner kinetochore, but at the spindle poles or corona instead.

Furthermore, the outer kinetochore proteins play an important role in ciliary disassembly and cell division. PLK1 is one of the proteins that is rooted deeply in both processes. In addition, cell cycle protein TTK (also known as MPS1) also plays a role in ciliary disassembly. During M phase, TTK is required for the localization of CENPE to the kinetochores [124, 125]. Here, it regulates APC/C-CDC20 activity through MAD2L1 of the MCC. After cell division, TTK moves to the base of the cilia, where it is required for recruitment of mitochondrial channel protein VDAC3 and, in turn, ciliary disassembly [126]. VDAC3 is thought to be essential for UPS-mediated degradation of multiple targets during ciliary disassembly [127]. It has not been shown if TTK also regulates CDC20 in ciliary disassembly as it does during cell division.

\section{Overlap in microtubule regulators between mitosis and ciliary disassembly}

In contrast to outer kinetochore proteins PLK1 and TTK, the KMN complex that binds the MTs in the kinetochores does not seem to be conserved in cilia. Instead, the ciliary tip module, positioned at the kinetochore corona, is thought to connect the ciliary membrane to the MTs. This docking is performed by the plus-end tracking tip proteins (+TIP), MTbinding proteins, and the IFT complex [128-130]. The plusend tracking tip proteins MAPRE1 (EB1) and MAPRE3 (EB3) are conserved between kinetochores and cilia, but also play a role in the organization of other organelles [131-133]. At the kinetochores, they form a complex with CLASP1, CLASP2, CLIP1, CLIP2 and CKAP5 (also known as chTOG) $[134,135]$. Even though these interacting proteins are not directly linked to ciliary disassembly, it is interesting to see that not CKAP5, but another TOG-domain protein, TOGARAM1, is involved in MT organization in cilia [136] and that recent studies have linked TOGARAM1 to Joubert syndrome [137]. Furthermore, CLASP1, CLASP2, CLIP1 and CLIP2 interactors are previously indicated to have a role in ciliary disassembly, including CENPE, CENPJ, PLK1, and dynein regulator PAFAH1B1. Together these data suggest that there might be a role for more of the +TIP proteins in ciliary disassembly, or that these cell cycle proteins have a counterpart with similar protein domain structures, which shadows their role in ciliary disassembly, as seen for CKAP5 and TOGARAM1.

In addition to the + TIP module, other MT regulators localized at the kinetochore corona during $M$ phase have been indicated to position towards the cilia during G0/G1. These include, CENPE, CENPF, and the Dynein regulatory complex. Even though most of the family of CENP proteins are positioned at the inner kinetochore, CENPE and CENPF localize at the corona $[138,139]$. CENPE is a plus-end directed motor protein that counteracts the minusend directed Dynein proteins in positioning of the kinetochores and end-on attachment of the MTs [112, 140, 141]. CENPF is required for localization of the NDE1/NDEL1/ PAFAH1B1 module at the kinetochores $[111,138]$. On the other hand, during quiescence, CENPF localizes at the centrioles at the base of the cilia and has been shown to interact with CEP290 and ATF4 [118]. ATF4 is linked to skeletal and neuronal development $[142,143]$. CEP290 is located at and just below the ciliary TZ during G0/G1 [144], and mutations in CEP290 cause a variety of ciliopathies (as discussed above). These examples underpin the importance of understanding the role of kinetochore proteins in ciliary function.

NDE1 regulates dynein and is required for the positioning and functioning of a variety of cell organelles. Dynein is a minus-end directed motor protein and together with dynactin important in MT elongation [145]. NDE1, together with NDEL1 and PAFAH1B1, regulates nuclear migration, Golgi localization, kinetochore positioning, and ciliary disassembly [146, 147]. The complex is recruited to the mother centriole by CENPJ [81]. Targeting of NDE1 or NDEL1 to the membrane through palmitoylation lowers the amount of cytoplasmic dynein and decreases dynein-mediated trafficking $[146,148]$. Deletion of NDE1 results in a loss of membrane bound dynein, leading to microcephaly [149]. This 
same phenotype is seen with mutations in other proteins that regulate both the cell cycle and ciliary disassembly, among which CENPF, CENPJ, and KIF2A [86, 118, 150].

During G0/G1, NDE1 stimulates ciliary disassembly and cell cycle re-entry in an AURKA-dependent manner [147]. To allow ciliary elongation during ciliogenesis, CDK5 primes NDE1 for polyubiquitination by the E3 ligase FBXW7, targeting NDE1 for UPS-mediated degradation [151]. CDK5, NDE1 and PAFAH1B1 are essential in neural migration during brain development and mutations have been shown to cause lissencephaly [149, 152-155]. Of interest is that NDE1 and NDEL1 are located near the mother centriole at the base of the cilia during quiescence, while their downstream target PAFAH1B1, is located along the ciliary axoneme in a similar manner as Dynein $[111,146$, 156] (Fig. 3b).

Dynein associates with the nuclear pore complex (NPC) members RANBP2 (NUP358), RANGAP1 and XPO1 (CARM1) at the kinetochores and this same association has been suggested to occur in the ciliary axoneme as a counter partner of the RAN/Importin complex that is required for nuclear and ciliary gating [107, 157-159]. This idea is supported by the fact that multiple nuclear pore (NUP) complex members have been identified to interact with IFTs at the base of the cilia in G0/G1 phase [19, 160]. For instance, NUP62 indirectly interacts with IQCB1 (NPHP5) and CEP290 (NPHP6) through NUP93, and it is targeted towards the ciliary tip in a KIF17-dependent manner [19]. Furthermore, inhibition of XPO1 has been shown to increase ciliary localization of SHH transcription factor GLI2 [160]. Lastly, it has been shown that RANBP2 is required for correct photoreceptor formation and functioning in mice [161]. It would be valuable to identify the entire Dynein/XPO1 complex in cilia, and to see if it functions in a similar manner as it does during the cell cycle.

A last interesting note is that most of the kinetochore corona cell cycle regulators are positioned at the base of the cilia during G0/G1, while many of the MT regulators are located along the ciliary axoneme or at the ciliary tip. Getting a better understanding of the localization and function of these modules in ciliary disassembly might prove valuable in the search for therapeutic targets.

\section{Overlapping mechanisms reveal cell cycle regulators with a potential role in ciliary resorption}

Next to the MT regulators, there is a second group of proteins positioned at the kinetochore that plays a role in ciliary disassembly, being the APC/C and its regulators (Fig. 3a). Studying mitotic interactors of this complex in a ciliary-specific manner might reveal novel insight into the mechanism of ciliary resorption.
First, a role for BUB1B, ANAPC2 and CDC20 is well established in ciliary disassembly, however not all of the APC/C members and its regulators have been indicated to function in ciliary processes as of yet (Fig. 3b). For example, ANAPC2 and CDC20 have been shown to localize to the base of the cilia prior to and during ciliary disassembly, however, FZR1 localization at the base of the cilia could not be confirmed in quiescent cells or during ciliary disassembly [53]. To our knowledge, other APC/C components have not been studied with respect to ciliary localization thus far. Furthermore, the MCC is indicated to downregulate APC/C-CDC20 activity during G0/G1, and MCC-member BUB1B is a negative regulator of ciliary disassembly [54]. Nonetheless, since all MCC studies, thus, far focused on the cell cycle, it remains to be demonstrated the other MCC members, MAD2L1 and BUB3, are indeed also inhibiting CDC20 at the base of the cilia. The same accounts for CDC20-regulators BUB1 and the RZZ. During mitosis, BUB 1 is required for BUB1B and RZZ recruitment to the kinetochores [114]. Here, the RZZ complex stimulates the MCC in downregulation of APC/C-CDC20 activity. Next to the MCC, the BUB1-PLK1 complex inhibits CDC20 in an MCC-independent manner, but it is unclear if this mechanism also functions during disassembly [162]. It would be interesting to see if MAD2L, BUB3, BUB1 and the RZZ have a similar mechanism of regulating BUB1B and CDC20 in ciliary disassembly by determining the exact spatiotemporal positions of these interactors. Second, another interesting target to study regarding ciliary resorption is BORA, since AURKA activation by BORA has been shown to be essential in mitosis, but it remains unclear if the same applies to ciliary resorption [163]. During anaphase, PLK1 marks BORA and AURKA for proteasomal degradation. The latter is regulated through the anaphase promoting complex/cyclosome (APC/C), which can polyubiquitinate AURKA after the complex is activated through FZR1. Another method through which the APC/C might influence AURKA in ciliary resorption is the APC/C E2 ubiquitin-conjugating enzymes UBE2C. This protein is required for polyubiquitination in the process of APC/C-dependent UPS-mediated degradation [164]. Inhibition of UBE2C leads to a reduction of AURKA phosphorylation. It remains unclear if it functions as an E2 after APC/C activation through CDC20 or FZR1 and if this process also occurs during ciliary resorption. Lastly, the later also applies to PTP4A3, which promotes AURKA degradation through APC/C-FZR1 in colorectal cancer progression [165]. Studying the role of BORA, UBE2C and PTP4A3 in a ciliary resorption-specific manner might reveal new cilium disassembly mechanisms that overlap with known mitotic mechanisms. 


\section{Finding therapeutic targets by scrutinizing the conserved mechanisms}

Looking at the type of disorders associated with defects in ciliary disassembly, we have to distinguish two groups of patients. On the one hand, the patients suffering from ciliopathies and developmental disorders, which are more often related to ciliogenesis and ciliary excision. These ciliopathies are caused by genetic predispositions leading to disruptions in embryonic development. Consequently, these are often embryonically lethal, hence, for this group of patients, finding the causative mutation is more relevant for genetic counselling of the expecting parents, than finding a therapeutic target. On the other hand, we have the group of patients showing MVA and different types of tumours. Although ciliogenesis defects are not typically linked to increased tumour formation [166], the opposite is true for ciliary disassembly proteins regulators $[9,167,168]$. The latter might be explained by the double role of ciliary resorption proteins in mitosis.

To get a better understanding of the possible therapeutic targets, the proteins involved in post-translational modifications (PTMs) might reveal interesting targets. PTMs are essential for proper ciliary disassembly. One example is microtubule acetylation, required for dimerization and autoassembly to form the ciliary axoneme and, in turn, tubulin deacetylation by HDAC6 is required for ciliary disassembly $[35,169]$. Another example is the highly diverse PLK1 that has opposing roles in both ciliary disassembly and mitosis based on its spatiotemporal position. Lastly, ubiquitination has been shown to increase upon the initiation of ciliary disassembly. Moreover, the relevance of UPS-mediated degradation in cell division and signal transduction has been known for almost 30 years now [170-173].

Getting a better understanding of the conservation between these two mechanisms is essential in the development of cancer treatment. One excellent example of this is the targeting of NEDD9 as an AURKA stabilizer in ciliary disassembly to potentiate AURKA treatment in breast tumours [37].

\section{Conclusion}

In summary, many proteins involved in cilium disassembly also play a role in cell division. This conservation is not only seen for centrosomal proteins, but also for a range of other protein, among which kinetochore proteins and MT regulators. Misregulation of these proteins or mutations in the genes encoding them can lead to a variety of diseases affecting neuronal development, or can lead to tumour development across a range of different cancers. Getting a better understanding of the conservation between mitosis and cilium resorption might prove pivotal in developing therapeutic targets for these diseases.

Supplementary Information The online version contains supplementary material available at https://doi.org/10.1007/s00018-021-03827-5.

Author contributions $\mathrm{CD}$ and RR manuscript draft. CD manuscript writing. CD figures. RR manuscript editing. $\mathrm{CD}$ and $\mathrm{RR}$ review and final approval of the manuscript.

Funding This work was financially supported by an institutional $\mathrm{PhD}$ Grant (Radboud Institute for Molecular Life Sciences) to R.R.

\section{Declarations}

Conflict of interest The authors declare they have no conflict of interest.

Open Access This article is licensed under a Creative Commons Attribution 4.0 International License, which permits use, sharing, adaptation, distribution and reproduction in any medium or format, as long as you give appropriate credit to the original author(s) and the source, provide a link to the Creative Commons licence, and indicate if changes were made. The images or other third party material in this article are included in the article's Creative Commons licence, unless indicated otherwise in a credit line to the material. If material is not included in the article's Creative Commons licence and your intended use is not permitted by statutory regulation or exceeds the permitted use, you will need to obtain permission directly from the copyright holder. To view a copy of this licence, visit http://creativecommons.org/licenses/by/4.0/.

\section{References}

1. Ross AJ, May-Simera H, Eichers ER, Kai M, Hill J, Jagger DJ, Leitch CC, Chapple JP, Munro PM, Fisher S, Tan PL, Phillips HM, Leroux MR, Henderson DJ, Murdoch JN, Copp AJ, Eliot MM, Lupski JR, Kemp DT, Dollfus H, Tada M, Katsanis N, Forge A, Beales PL (2005) Disruption of Bardet-Biedl syndrome ciliary proteins perturbs planar cell polarity in vertebrates. Nat Genet 37(10):1135-1140. https://doi.org/10.1038/ ng 1644

2. Simons M, Gloy J, Ganner A, Bullerkotte A, Bashkurov M, Kronig C, Schermer B, Benzing T, Cabello OA, Jenny A, Mlodzik M, Polok B, Driever W, Obara T, Walz G (2005) Inversin, the gene product mutated in nephronophthisis type II, functions as a molecular switch between Wnt signaling pathways. Nat Genet 37(5):537-543. https://doi.org/10.1038/ng1552

3. Huangfu D, Liu A, Rakeman AS, Murcia NS, Niswander L, Anderson KV (2003) Hedgehog signalling in the mouse requires intraflagellar transport proteins. Nature 426(6962):8387. https://doi.org/10.1038/nature02061

4. Rohatgi R, Milenkovic L, Scott MP (2007) Patched1 regulates hedgehog signaling at the primary cilium. Science 317:372-376

5. Pampliega O, Orhon I, Patel B, Sridhar S, Diaz-Carretero A, Beau I, Codogno P, Satir BH, Satir P, Cuervo AM (2013) Functional interaction between autophagy and ciliogenesis. Nature 502(7470):194-200. https://doi.org/10.1038/nature12639

6. Tang Z, Lin MG, Stowe TR, Chen S, Zhu M, Stearns T, Franco B, Zhong Q (2013) Autophagy promotes primary 
ciliogenesis by removing OFD1 from centriolar satellites. Nature 502(7470):254-257. https://doi.org/10.1038/natur e12606

7. Hildebrandt F, Benzing T, Katsanis N (2011) Ciliopathies. N Engl J Med 364(16):1533-1543. https://doi.org/10.1056/ NEJMra1010172

8. Peixoto E, Richard S, Pant K, Biswas A, Gradilone SA (2020) The primary cilium: its role as a tumor suppressor organelle. Biochem Pharmacol 175:113906. https://doi.org/10.1016/j.bcp. 2020.113906

9. Fabbri L, Bost F, Mazure NM (2019) Primary cilium in cancer hallmarks. Int J Mol Sci 20(6):1336. https://doi.org/10.3390/ ijms20061336

10. Higgins M, Obaidi I, McMorrow T (2019) Primary cilia and their role in cancer. Oncol Lett 17(3):3041-3047. https://doi. org/10.3892/ol.2019.9942

11. Nishimura Y, Kasahara K, Shiromizu T, Watanabe M, Inagaki M (2019) Primary cilia as signaling hubs in health and disease. Adv Sci 6(1):1801138. https://doi.org/10.1002/advs.201801138

12. Joukov V, De Nicolo A (2019) The centrosome and the primary cilium: the yin and yang of a hybrid organelle. Cells 8(7):701. https://doi.org/10.3390/cells8070701

13. Pedersen LB, Veland IR, Schroder JM, Christensen ST (2008) Assembly of primary cilia. Dev Dynam 237(8):1993-2006. https://doi.org/10.1002/dvdy.21521

14. Boldt K, van Reeuwijk J, Lu Q, Koutroumpas K, Nguyen TMT, Texier Y, van Beersum SEC, Horn N, Willer JR, Mans DA, Dougherty G, Lamers IJC, Coene KLM, Arts HH, Betts MJ, Beyer T, Bolat E, Gloeckner CJ, Haidari K, Hetterschijt L, Iaconis D, Jenkins D, Klose F, Knapp B, Latour B, Letteboer SJF, Marcelis CL, Mitic D, Morleo M, Oud MM, Riemersma M, Rix S, Terhal PA, Toedt G, van Dam TJP, de Vrieze E, Wissinger Y, Wu KM, Apic G, Beales PL, Blacque OE, Gibson TJ, Huynen MA, Katsanis N, Kremer H, Omran H, van Wijk E, Wolfrum U, Kepes F, Davis EE, Franco B, Giles RH, Ueffing M, Russell RB, Roepman R, Grp UKRD (2016) An organelle-specific protein landscape identifies novel diseases and molecular mechanisms. Nat Commun 7:11491. https://doi.org/10.1038/ncomms11491

15. Garcia G 3rd, Raleigh DR, Reiter JF (2018) How the ciliary membrane is organized inside-out to communicate outside-in. Curr Biol 28(8):R421-R434. https://doi.org/10.1016/j.cub. 2018.03.010

16. Nachury MV (2018) The molecular machines that traffic signaling receptors into and out of cilia. Curr Opin Cell Biol 51:124-131. https://doi.org/10.1016/j.ceb.2018.03.004

17. Odabasi E, Gul S, Kavakli IH, Firat-Karalar EN (2019) Centriolar satellites are required for efficient ciliogenesis and ciliary content regulation. Embo Reports. https://doi.org/10.15252/ embr.201947723

18. Prosser SL, Pelletier L (2020) Centriolar satellite biogenesis and function in vertebrate cells. J Cell Sci 133(1):jcs239566. https://doi.org/10.1242/jcs.239566

19. Takao D, Wang L, Boss A, Verhey KJ (2017) Protein interaction analysis provides a map of the spatial and temporal organization of the ciliary gating zone. Curr Biol 27(15):2296-2306. e3. https://doi.org/10.1016/j.cub.2017.06.044

20. Wang LM, Gu LX, Meng D, Wu Q, Deng HT, Pan JM (2017) Comparative proteomics reveals timely transport into cilia of regulators or effectors as a mechanism underlying ciliary disassembly. J Proteome Res 16(7):2410-2418. https://doi.org/10. 1021/acs.jproteome.6b01048

21. Ishikawa H, Marshall WF (2011) Ciliogenesis: building the cell's antenna. Nat Rev Mol Cell Biol 12(4):222-234. https:// doi.org/10.1038/nrm3085
22. Keeling J, Tsiokas L, Maskey D (2016) Cellular mechanisms of ciliary length control. Cells 5(1):6. https://doi.org/10.3390/ cells5010006

23. Pugacheva EN, Jablonski SA, Hartman TR, Henske EP, Golemis EA (2007) HEF1-dependent aurora a activation induces disassembly of the primary cilium. Cell 129(7):1351-1363. https://doi.org/10.1016/j.cell.2007.04.035

24. Pedersen LB, Rosenbaum JL (2008) Intraflagellar transport (Ift): role in ciliary assembly, resorption and signalling. Curr Top Dev Biol 85:23-61. https://doi.org/10.1016/S00702153(08)00802-8

25. Mirvis M, Siemers KA, Nelson WJ, Stearns TP (2019) Primary cilium loss in mammalian cells occurs predominantly by wholecilium shedding. Plos Biol 17(7):e3000381. https://doi.org/10. 1371/journal.pbio.3000381

26. Cao M, Ning J, Hernandez-Lara CI, Belzile O, Wang Q, Dutcher SK, Liu Y, Snell WJ (2015) Uni-directional ciliary membrane protein trafficking by a cytoplasmic retrograde IFT motor and ciliary ectosome shedding. Elife. https://doi.org/10.7554/eLife. 05242

27. Wang J, Barr MM (2016) Ciliary extracellular vesicles: txt msg organelles. Cell Mol Neurobiol 36(3):449-457. https://doi.org/ 10.1007/s10571-016-0345-4

28. Nachury MV, Mick DU (2019) Establishing and regulating the composition of cilia for signal transduction. Nat Rev Mol Cell Biol 20(7):389-405. https://doi.org/10.1038/s41580-019-0116-4

29. Tuxhorn J, Daise T, Dentler WL (1998) Regulation of flagellar length in Chlamydomonas. Cell Motil Cytoskeleton 40(2):133146. https://doi.org/10.1002/(SICI) 1097-0169(1998)40:2\% 3c133::AID-CM3\%3e3.0.CO;2-G

30. Pan J, Wang Q, Snell WJ (2004) An aurora kinase is essential for flagellar disassembly in Chlamydomonas. Dev Cell 6(3):445451. https://doi.org/10.1016/s1534-5807(04)00064-4

31. Phua SC, Chiba S, Suzuki M, Su E, Roberson EC, Pusapati GV, Schurmans S, Setou M, Rohatgi R, Reiter JF, Ikegami K, Inoue $\mathrm{T}$ (2017) Dynamic remodeling of membrane composition drives cell cycle through primary cilia excision. Cell 168(1-2):264-279. e15. https://doi.org/10.1016/j.cell.2016.12.032

32. Boesger J, Wagner V, Weisheit W, Mittag M (2014) Comparative phosphoproteomics to identify targets of the clock-relevant casein kinase 1 in $C$. reinhardtii flagella. Methods Mol Biol 1158:187-202. https://doi.org/10.1007/978-1-4939-0700-7_12

33. Jeffries EP, Di Filippo M, Galbiati F (2019) Failure to reabsorb the primary cilium induces cellular senescence. FASEB J 33(4):4866-4882. https://doi.org/10.1096/fj.201801382R

34. Liang YW, Meng D, Zhu B, Pan JM (2016) Mechanism of ciliary disassembly. Cell Mol Life Sci 73(9):1787-1802. https://doi.org/ 10.1007/s00018-016-2148-7

35. Hubbert C, Guardiola A, Shao R, Kawaguchi Y, Ito A, Nixon A, Yoshida M, Wang XF, Yao TP (2002) HDAC6 is a microtubuleassociated deacetylase. Nature 417(6887):455-458. https://doi. org/10.1038/417455a

36. Ding J, Swain JE, Smith GD (2011) Aurora kinase-A regulates microtubule organizing center (MTOC) localization, chromosome dynamics, and histone-H3 phosphorylation in mouse oocytes. Mol Reprod Dev 78(2):80-90. https://doi.org/10.1002/ mrd. 21272

37. Ice RJ, McLaughlin SL, Livengood RH, Culp MV, Eddy ER, Ivanov AV, Pugacheva EN (2013) NEDD9 depletion destabilizes aurora A kinase and heightens the efficacy of aurora A inhibitors: implications for treatment of metastatic solid tumors. Cancer Res 73(10):3168-3180. https://doi.org/10.1158/0008-5472. CAN-12-4008

38. Plotnikova OV, Nikonova AS, Loskutov YV, Kozyulina PY, Pugacheva EN, Golemis EA (2012) Calmodulin activation of aurora-A kinase (AURKA) is required during ciliary disassembly 
and in mitosis. Mol Biol Cell 23(14):2658-2670. https://doi.org/ 10.1091/mbc.E11-12-1056

39. Plotnikova OV, Pugacheva EN, Dunbrack RL, Golemis EA (2010) Rapid calcium-dependent activation of aurora-A kinase. Nat Commun 1:64. https://doi.org/10.1038/ncomms1061

40. Maharjan Y, Lee JN, Kwak S, Lim H, Dutta RK, Liu ZQ, So HS, Park R (2018) Autophagy alteration prevents primary cilium disassembly in RPE1 cells. Biochem Bioph Res Co 500(2):242-248. https://doi.org/10.1016/j.bbrc.2018.04.051

41. Wang G, Chen Q, Zhang XY, Zhang BY, Zhuo XL, Liu JJ, Jiang Q, Zhang CM (2013) PCM1 recruits Plk1 to the pericentriolar matrix to promote primary cilia disassembly before mitotic entry. J Cell Sci 126(6):1355-1365

42. Kinzel D, Boldt K, Davis EE, Burtscher I, Trumbach D, Diplas B, Attie-Bitach T, Wurst W, Katsanis N, Ueffing M, Lickert $\mathrm{H}$ (2010) Pitchfork regulates primary cilia disassembly and left-right asymmetry. Dev Cell 19(1):66-77. https://doi.org/10. 1016/j.devcel.2010.06.005

43. Berman SA, Wilson NF, Haas NA, Lefebvre PA (2003) A novel MAP kinase regulates flagellar length in Chlamydomonas. Curr Biol 13(13):1145-1149. https://doi.org/10.1016/s0960-9822(03) 00415-9

44. Eggenschwiler JT, Anderson KV (2007) Cilia and developmental signaling. Annu Rev Cell Dev Bi 23:345-373. https://doi.org/10. 1146/annurev.cellbio.23.090506.123249

45. Lee KH, Johmura Y, Yu LR, Park JE, Gao Y, Bang JK, Zhou M, Veenstra TD, Yeon Kim B, Lee KS (2012) Identification of a novel Wnt5a-CK1 varepsilon-Dv12-Plk1-mediated primary cilia disassembly pathway. EMBO J 31(14):3104-3117. https://doi. org/10.1038/emboj.2012.144

46. Miyamoto T, Hosoba K, Ochiai H, Royba E, Izumi H, Sakuma T, Yamamoto T, Dynlacht BD, Matsuura S (2015) The microtubule-depolymerizing activity of a mitotic kinesin protein KIF2A drives primary cilia disassembly coupled with cell proliferation. Cell Rep 10(5):664-673. https://doi.org/10.1016/j.celrep.2015. 01.003

47. Karaca E, Harel T, Pehlivan D, Jhangiani SN, Gambin T, Coban Akdemir Z, Gonzaga-Jauregui C, Erdin S, Bayram Y, Campbell IM, Hunter JV, Atik MM, Van Esch H, Yuan B, Wiszniewski W, Isikay S, Yesil G, Yuregir OO, Tug Bozdogan S, Aslan H, Aydin H, Tos T, Aksoy A, De Vivo DC, Jain P, Geckinli BB, Sezer O, Gul D, Durmaz B, Cogulu O, Ozkinay F, Topcu V, Candan S, Cebi AH, Ikbal M, Yilmaz Gulec E, Gezdirici A, Koparir E, Ekici F, Coskun S, Cicek S, Karaer K, Koparir A, Duz MB, Kirat E, Fenercioglu E, Ulucan H, Seven M, Guran T, Elcioglu N, Yildirim MS, Aktas D, Alikasifoglu M, Ture M, Yakut T, Overton JD, Yuksel A, Ozen M, Muzny DM, Adams DR, Boerwinkle E, Chung WK, Gibbs RA, Lupski JR (2015) Genes that affect brain structure and function identified by rare variant analyses of mendelian neurologic disease. Neuron 88(3):499-513. https:// doi.org/10.1016/j.neuron.2015.09.048

48. Baker K, Beales PL (2009) Making sense of cilia in disease: the human ciliopathies. Am J Med Genet C Semin Med Genet 151C(4):281-295. https://doi.org/10.1002/ajmg.c.30231

49. Simon D, Laloo B, Barillot M, Barnetche T, Blanchard C, Rooryck C, Marche M, Burgelin I, Coupry I, Chassaing N, Gilbert-Dussardier B, Lacombe D, Grosset C, Arveiler B (2010) A mutation in the 3'-UTR of the HDAC6 gene abolishing the posttranscriptional regulation mediated by hsa-miR-433 is linked to a new form of dominant X-linked chondrodysplasia. Hum Mol Genet 19(10):2015-2027. https://doi.org/10.1093/hmg/ddq083

50. Nikonova AS, Astsaturov I, Serebriiskii IG, Dunbrack RL Jr, Golemis EA (2013) Aurora A kinase (AURKA) in normal and pathological cell division. Cell Mol Life Sci 70(4):661-687. https://doi.org/10.1007/s00018-012-1073-7
51. Jeng YM, Peng SY, Lin CY, Hsu HC (2004) Overexpression and amplification of aurora-A in hepatocellular carcinoma. Clin Cancer Res 10(6):2065-2071. https://doi.org/10.1158/1078-0432. ccr-1057-03

52. Bertolin G, Tramier M (2020) Insights into the non-mitotic functions of aurora kinase A: more than just cell division. Cell Mol Life Sci 77(6):1031-1047. https://doi.org/10.1007/ s00018-019-03310-2

53. Wang W, Wu T, Kirschner MW (2014) The master cell cycle regulator APC-Cdc20 regulates ciliary length and disassembly of the primary cilium. Elife 3:e03083. https://doi.org/10.7554/ eLife.03083

54. Miyamoto T, Porazinski S, Wang HJ, Borovina A, Ciruna B, Shimizu A, Kajii T, Kikuchi A, Furutani-Seiki M, Matsuura S (2011) Insufficiency of BUBR1, a mitotic spindle checkpoint regulator, causes impaired ciliogenesis in vertebrates. Hum Mol Genet 20(10):2058-2070. https://doi.org/10.1093/hmg/ddr090

55. Ganner A, Lienkamp S, Schafer T, Romaker D, Wegierski T, Park TJ, Spreitzer S, Simons M, Gloy J, Kim E, Wallingford JB, Walz G (2009) Regulation of ciliary polarity by the APC/C. Proc Natl Acad Sci USA 106(42):17799-17804. https://doi.org/ 10.1073/pnas.0909465106

56. van Leuken R, Clijsters L, van Zon W, Lim D, Yao X, Wolthuis RM, Yaffe MB, Medema RH, van Vugt MA (2009) Polo-like kinase- 1 controls aurora A destruction by activating APC/CCdh1. PLoS One 4(4):e5282. https://doi.org/10.1371/journal. pone.0005282

57. Uddin B, Partscht P, Chen NP, Neuner A, Weiss M, Hardt R, Jafarpour A, Hessling B, Ruppert T, Lorenz H, Pereira G, Schiebel E (2019) The human phosphatase CDC14A modulates primary cilium length by regulating centrosomal actin nucleation. EMBO Rep 20(1):e46544. https://doi.org/10.15252/embr.20184 6544

58. Eckerdt F, Strebhardt K (2006) Polo-like kinase 1: target and regulator of anaphase-promoting complex/cyclosome-dependent proteolysis. Cancer Res 66(14):6895-6898. https://doi.org/10. 1158/0008-5472.CAN-06-0358

59. Lindon C, Pines J (2004) Ordered proteolysis in anaphase inactivates Plk1 to contribute to proper mitotic exit in human cells. J Cell Biol 164(2):233-241. https://doi.org/10.1083/jcb.20030 9035

60. Suijkerbuijk SJE, van Osch MHJ, Bos FL, Hanks S, Rahman N, Kops GJPL (2010) Molecular causes for BUBR1 dysfunction in the human cancer predisposition syndrome mosaic variegated aneuploidy. Cancer Res 70(12):4891-4900. https://doi. org/10.1158/0008-5472.Can-09-4319

61. Matsuura S, Matsumoto Y, Morishima K, Izumi H, Matsumoto H, Ito E, Tsutsui K, Kobayashi J, Tauchi H, Kajiwara Y, Hama S, Kurisu K, Tahara H, Oshimura M, Komatsu K, Ikeuchi T, Kajii T (2006) Monoallelic BUB1B mutations and defective mitotic-spindle checkpoint in seven families with premature chromatid separation (PCS) syndrome. Am J Med Genet A 140a(4):358-367. https://doi.org/10.1002/ajmg.a.31069

62. Moniz L, Dutt P, Haider N, Stambolic V (2011) Nek family of kinases in cell cycle, checkpoint control and cancer. Cell Div 6:18. https://doi.org/10.1186/1747-1028-6-18

63. Mahjoub MR, Trapp ML, Quarmby LM (2005) NIMA-related kinases defective in murine models of polycystic kidney diseases localize to primary cilia and centrosomes. J Am Soc Nephrol 16(12):3485-3489. https://doi.org/10.1681/ASN. 2005080824

64. Thiel C, Kessler K, Giessl A, Dimmler A, Shalev SA, von der Haar S, Zenker M, Zahnleiter D, Stoss H, Beinder E, Abou Jamra R, Ekici AB, Schroder-Kress N, Aigner T, Kirchner T, Reis A, Brandstatter JH, Rauch A (2011) NEK1 mutations cause 
short-rib polydactyly syndrome type majewski. Am J Hum Genet 88(1):106-114. https://doi.org/10.1016/j.ajhg.2010.12.004

65. White MC, Quarmby LM (2008) The NIMA-family kinase, Nek1 affects the stability of centrosomes and ciliogenesis. Bmc Cell Biol 9:29. https://doi.org/10.1186/1471-2121-9-29

66. Al-Jassar C, Andreeva A, Barnabas DD, McLaughlin SH, Johnson CM, Yu M, van Breugel M (2017) The ciliopathy-associated cep104 protein interacts with tubulin and Nek1 kinase. Structure 25(1):146-156. https://doi.org/10.1016/j.str.2016.11.014

67. Kim S, Lee K, Choi JH, Ringstad N, Dynlacht BD (2015) Nek2 activation of Kif24 ensures cilium disassembly during the cell cycle. Nat Commun 6:8087. https://doi.org/10.1038/ncomm s9087

68. Nishiguchi KM, Tearle RG, Liu YP, Oh EC, Miyake N, Benaglio P, Harper S, Koskiniemi-Kuendig H, Venturini G, Sharon D, Koenekoop RK, Nakamura M, Kondo M, Ueno S, Yasuma TR, Beckmann JS, Ikegawa S, Matsumoto N, Terasaki H, Berson EL, Katsanis N, Rivolta C (2013) Whole genome sequencing in patients with retinitis pigmentosa reveals pathogenic DNA structural changes and NEK2 as a new disease gene. Proc Natl Acad Sci USA 110(40):16139-16144. https://doi.org/10.1073/ pnas. 1308243110

69. Otto EA, Schermer B, Obara T, O'Toole JF, Hiller KS, Mueller AM, Ruf RG, Hoefele J, Beekmann F, Landau D, Foreman JW, Goodship JA, Strachan T, Kispert A, Wolf MT, Gagnadoux MF, Nivet H, Antignac C, Walz G, Drummond IA, Benzing T, Hildebrandt F (2003) Mutations in INVS encoding inversin cause nephronophthisis type 2, linking renal cystic disease to the function of primary cilia and left-right axis determination. Nat Genet 34(4):413-420. https://doi.org/10.1038/ng1217

70. Lienkamp S, Ganner A, Walz G (2012) Inversin, Wnt signaling and primary cilia. Differentiation 83(2):S49-S55. https://doi.org/ 10.1016/j.diff.2011.11.012

71. Morgan D, Eley L, Sayer J, Strachan T, Yates LM, Craighead AS, Goodship JA (2002) Expression analyses and interaction with the anaphase promoting complex protein Apc2 suggest a role for inversin in primary cilia and involvement in the cell cycle. Hum Mol Genet 11(26):3345-3350. https://doi.org/10.1093/hmg/11. 26.3345

72. Patnaik SR, Kretschmer V, Brucker L, Schneider S, Volz AK, Oancea-Castillo LDR, May-Simera HL (2019) Bardet-Biedl syndrome proteins regulate cilia disassembly during tissue maturation. Cell Mol Life Sci 76(4):757-775. https://doi.org/10.1007/ s00018-018-2966-x

73. Shiba D, Manning DK, Koga H, Beier DR, Yokoyama T (2010) Inv acts as a molecular anchor for Nphp3 and Nek8 in the proximal segment of primary cilia. Cytoskeleton (Hoboken) 67(2):112-119. https://doi.org/10.1002/cm.20428

74. Hoff S, Halbritter J, Epting D, Frank V, Nguyen TM, van Reeuwijk J, Boehlke C, Schell C, Yasunaga T, Helmstadter M, Mergen M, Filhol E, Boldt K, Horn N, Ueffing M, Otto EA, Eisenberger T, Elting MW, van Wijk JA, Bockenhauer D, Sebire NJ, Rittig S, Vyberg M, Ring T, Pohl M, Pape L, Neuhaus TJ, Elshakhs NA, Koon SJ, Harris PC, Grahammer F, Huber TB, Kuehn EW, Kramer-Zucker A, Bolz HJ, Roepman R, Saunier S, Walz G, Hildebrandt F, Bergmann C, Lienkamp SS (2013) ANKS6 is a central component of a nephronophthisis module linking NEK8 to INVS and NPHP3. Nat Genet 45(8):951-956. https://doi.org/ 10.1038/ng.2681

75. Grampa V, Delous M, Zaidan M, Odye G, Thomas S, Elkhartoufi N, Filhol E, Niel O, Silbermann F, Lebreton C, CollardeauFrachon S, Rouvet I, Alessandri JL, Devisme L, Dieux-Coeslier A, Cordier MP, Capri Y, Khung-Savatovsky S, Sigaudy S, Salomon R, Antignac C, Gubler MC, Benmerah A, Terzi F, AttieBitach T, Jeanpierre C, Saunier S (2016) Novel NEK8 mutations cause severe syndromic renal cystic dysplasia through YAP dysregulation. PLoS Genet 12(3):e1005894. https://doi.org/10. 1371/journal.pgen.1005894

76. Zhao B, Li L, Guan KL (2010) Hippo signaling at a glance. J Cell Sci 123(Pt 23):4001-4006. https://doi.org/10.1242/jcs.069070

77. Mikule K, Delaval B, Kaldis P, Jurcyzk A, Hergert P, Doxsey S (2007) Loss of centrosome integrity induces p38-p53-p21-dependent G1-S arrest. Nat Cell Biol 9(2):160-170. https://doi.org/ $10.1038 / \mathrm{ncb} 1529$

78. Villumsen BH, Danielsen JR, Povlsen L, Sylvestersen KB, Merdes A, Beli P, Yang YG, Choudhary C, Nielsen ML, Mailand N, Bekker-Jensen S (2013) A new cellular stress response that triggers centriolar satellite reorganization and ciliogenesis. EMBO J 32(23):3029-3040. https://doi.org/10.1038/emboj.2013. 223

79. Ki SM, Kim JH, Won SY, Oh SJ, Lee IY, Bae YK, Chung KW, Choi BO, Park B, Choi EJ, Lee JE (2020) CEP41-mediated ciliary tubulin glutamylation drives angiogenesis through AURKAdependent deciliation. EMBO Rep 21(2):e48290. https://doi.org/ 10.15252/embr.201948290

80. Elkins JM, Hewitson KS, McNeill LA, Seibel JF, Schlemminger I, Pugh CW, Ratcliffe PJ, Schofield CJ (2003) Structure of factor-inhibiting hypoxia-inducible factor (HIF) reveals mechanism of oxidative modification of HIF-1 alpha. J Biol Chem 278(3):1802-1806. https://doi.org/10.1074/jbc.C200644200

81. Gabriel E, Wason A, Ramani A, Gooi LM, Keller P, Pozniakovsky A, Poser I, Noack F, Telugu NS, Calegari F, Saric T, Hescheler J, Hyman AA, Gottardo M, Callaini G, Alkuraya FS, Gopalakrishnan J (2016) CPAP promotes timely cilium disassembly to maintain neural progenitor pool. EMBO J 35(8):803819. https://doi.org/10.15252/embj.201593679

82. Tang CJ, Fu RH, Wu KS, Hsu WB, Tang TK (2009) CPAP is a cell-cycle regulated protein that controls centriole length. Nat Cell Biol 11(7):825-831. https://doi.org/10.1038/ncb1889

83. Kohlmaier G, Loncarek J, Meng X, McEwen BF, Mogensen MM, Spektor A, Dynlacht BD, Khodjakov A, Gonczy P (2009) Overly long centrioles and defective cell division upon excess of the SAS-4-related protein CPAP. Curr Biol 19(12):1012-1018. https://doi.org/10.1016/j.cub.2009.05.018

84. Wang L, Hou S, Han YG (2016) Hedgehog signaling promotes basal progenitor expansion and the growth and folding of the neocortex. Nat Neurosci 19(7):888-896. https://doi.org/10.1038/ nn.4307

85. McIntyre RE, Chavali PL, Ismail O, Carragher DM, SanchezAndrade G, Forment JV, Fu BY, Velasco-Herrera MD, Edwards A, van der Weyden L, Yang FT, Ramirez-Solis R, Estabel J, Gallagher FA, Logan DW, Arends MJ, Tsang SH, Mahajan VB, Scudamore CL, White JK, Jackson SP, Gergely F, Adams DJ (2012) Disruption of mouse cenpj, a regulator of centriole biogenesis, phenocopies Seckel syndrome. PloS Genet 8(11):e1003022. https://doi.org/10.1371/journal.pgen.1003022

86. Leal GF, Roberts E, Silva EO, Costa SM, Hampshire DJ, Woods CG (2003) A novel locus for autosomal recessive primary microcephaly (MCPH6) maps to 13q12.2. J Med Genet 40(7):540-542. https://doi.org/10.1136/jmg.40.7.540

87. Spektor A, Tsang WY, Khoo D, Dynlacht BD (2007) Cep97 and CP110 suppress a cilia assembly program. Cell 130(4):678-690. https://doi.org/10.1016/j.cell.2007.06.027

88. Tsang WY, Bossard C, Khanna H, Peranen J, Swaroop A, Malhotra V, Dynlacht BD (2008) CP110 suppresses primary cilia formation through its interaction with CEP290, a protein deficient in human ciliary disease. Dev Cell 15(2):187-197. https:// doi.org/10.1016/j.devcel.2008.07.004

89. Tsang WY, Dynlacht BD (2013) CP110 and its network of partners coordinately regulate cilia assembly. Cilia 2(1):9. https:// doi.org/10.1186/2046-2530-2-9 
90. Schmidt TI, Kleylein-Sohn J, Westendorf J, Le Clech M, Lavoie SB, Stierhof YD, Nigg EA (2009) Control of centriole length by CPAP and CP110. Curr Biol 19(12):1005-1011. https://doi.org/ 10.1016/j.cub.2009.05.016

91. Rezabkova L, Kraatz SH, Akhmanova A, Steinmetz MO, Kammerer RA (2016) Biophysical and structural characterization of the centriolar protein cep104 interaction network. J Biol Chem 291(35):18496-18504. https://doi.org/10.1074/jbc.M116.739771

92. Jiang K, Toedt G, Montenegro Gouveia S, Davey NE, Hua S, van der Vaart B, Grigoriev I, Larsen J, Pedersen LB, Bezstarosti K, Lince-Faria M, Demmers J, Steinmetz MO, Gibson TJ, Akhmanova A (2012) A proteome-wide screen for mammalian SxIP motif-containing microtubule plus-end tracking proteins. Curr Biol 22(19):1800-1807. https://doi.org/10.1016/j.cub.2012. 07.047

93. Gogendeau D, Lemullois M, Le Borgne P, Castelli M, AubussonFleury A, Arnaiz O, Cohen J, Vesque C, Schneider-Maunoury S, Bouhouche K, Koll F, Tassin AM (2020) MKS-NPHP module proteins control ciliary shedding at the transition zone. Plos Biol 18(3):e3000640. https://doi.org/10.1371/journal.pbio.3000640

94. Sayer JA, Otto EA, O'Toole JF, Nurnberg G, Kennedy MA, Becker C, Hennies HC, Helou J, Attanasio M, Fausett BV, Utsch B, Khanna H, Liu Y, Drummond I, Kawakami I, Kusakabe T, Tsuda M, Ma L, Lee H, Larson RG, Allen SJ, Wilkinson CJ, Nigg EA, Shou CC, Lillo C, Williams DS, Hoppe B, Kemper MJ, Neuhaus T, Parisi MA, Glass IA, Petry M, Kispert A, Gloy J, Ganner A, Walz G, Zhu XL, Goldman D, Nurnberg P, Swaroop A, Leroux MR, Hildebrandt F (2006) The centrosomal protein nephrocystin- 6 is mutated in Joubert syndrome and activates transcription factor ATF4. Nat Genet 38(6):674-681. https:// doi.org/10.1038/ng1786

95. den Hollander AI, Koenekoop RK, Yzer S, Lopez I, Arends ML, Voesenek KEJ, Zonneveld MN, Strom TM, Meitinger T, Brunner HG, Hoyng CB, van den Born LI, Rohrschneider K, Cremers FPM (2006) Mutations in the CEP290 (NPHP6) gene are a frequent cause of leber congenital amaurosis. Am J Hum Genet 79(3):556-561. https://doi.org/10.1086/507318

96. Baala L, Audollent S, Martinovic J, Ozilou C, Babron MC, Sivanandamoorthy S, Saunier S, Salomon R, Gonzales M, Rattenberry E, Esculpavit C, Toutain A, Moraine C, Parent P, Marcorelles P, Dauge MC, Roume J, Le Merrer M, Meiner V, Meir K, Menez F, Beaufrere AM, Francannet C, Tantau J, Sinico M, Dumez Y, MacDonald F, Munnich A, Lyonnet S, Gubler MC, Genin E, Johnson CA, Vekemans M, Encha-Razavi F, AttieBitach T (2007) Pleiotropic effects of CEP290 (NPHP6) mutations extend to Meckel syndrome. Am J Hum Genet 81(1):170179. https://doi.org/10.1086/519494

97. Arts HH, Doherty D, van Beersum SE, Parisi MA, Letteboer SJ, Gorden NT, Peters TA, Marker T, Voesenek K, Kartono A, Ozyurek H, Farin FM, Kroes HY, Wolfrum U, Brunner HG, Cremers FP, Glass IA, Knoers NV, Roepman R (2007) Mutations in the gene encoding the basal body protein RPGRIP1L, a nephrocystin-4 interactor, cause Joubert syndrome. Nat Genet 39(7):882-888. https://doi.org/10.1038/ng2069

98. Delous M, Baala L, Salomon R, Laclef C, Vierkotten J, Tory K, Golzio C, Lacoste T, Besse L, Ozilou C, Moutkine I, Hellman NE, Anselme I, Silbermann F, Vesque C, Gerhardt C, Rattenberry E, Wolf MT, Gubler MC, Martinovic J, Encha-Razavi F, Boddaert N, Gonzales M, Macher MA, Nivet H, Champion G, Bertheleme JP, Niaudet P, McDonald F, Hildebrandt F, Johnson CA, Vekemans M, Antignac C, Ruther U, Schneider-Maunoury S, Attie-Bitach T, Saunier S (2007) The ciliary gene RPGRIP1L is mutated in cerebello-oculo-renal syndrome (Joubert syndrome type B) and Meckel syndrome. Nat Genet 39(7):875-881. https:// doi.org/10.1038/ng2039
99. Lambacher NJ, Bruel AL, van Dam TJ, Szymanska K, Slaats GG, Kuhns S, McManus GJ, Kennedy JE, Gaff K, Wu KM, van der Lee R, Burglen L, Doummar D, Riviere JB, Faivre L, Attie-Bitach T, Saunier S, Curd A, Peckham M, Giles RH, Johnson CA, Huynen MA, Thauvin-Robinet C, Blacque OE (2016) TMEM107 recruits ciliopathy proteins to subdomains of the ciliary transition zone and causes Joubert syndrome. Nat Cell Biol 18(1):122-131. https://doi.org/10.1038/ncb3273

100. Shaheen R, Almoisheer A, Faqeih E, Babay Z, Monies D, Tassan N, Abouelhoda M, Kurdi W, Al Mardawi E, Khalil MM, Seidahmed MZ, Alnemer M, Alsahan N, Sogaty S, Alhashem A, Singh A, Goyal M, Kapoor S, Alomar R, Ibrahim N, Alkuraya FS (2015) Identification of a novel MKS locus defined by TMEM107 mutation. Hum Mol Genet 24(18):5211-5218. https://doi.org/10.1093/hmg/ddv242

101. Edvardson S, Shaag A, Zenvirt S, Erlich Y, Hannon GJ, Shanske AL, Gomori JM, Ekstein J, Elpeleg O (2010) Joubert syndrome 2 (JBTS2) in Ashkenazi Jews is associated with a TMEM216 mutation. Am J Hum Genet 86(1):93-97. https://doi.org/10. 1016/j.ajhg.2009.12.007

102. Valente EM, Logan CV, Mougou-Zerelli S, Lee JH, Silhavy JL, Brancati F, Iannicelli M, Travaglini L, Romani S, Illi B, Adams M, Szymanska K, Mazzotta A, Lee JE, Tolentino JC, Swistun D, Salpietro CD, Fede C, Gabriel S, Russ C, Cibulskis K, Sougnez C, Hildebrandt F, Otto EA, Held S, Diplas BH, Davis EE, Mikula M, Strom CM, Ben-Zeev B, Lev D, Sagie TL, Michelson M, Yaron Y, Krause A, Boltshauser E, Elkhartoufi N, Roume J, Shalev S, Munnich A, Saunier S, Inglehearn C, Saad A, Alkindy A, Thomas S, Vekemans M, Dallapiccola B, Katsanis N, Johnson CA, Attie-Bitach T, Gleeson JG (2010) Mutations in TMEM216 perturb ciliogenesis and cause Joubert, Meckel and related syndromes. Nat Genet 42(7):619-625. https://doi.org/10.1038/ng. 594

103. Mollet G, Salomon R, Gribouval O, Silbermann F, Bacq D, Landthaler G, Milford D, Nayir A, Rizzoni G, Antignac C, Saunier $S$ (2002) The gene mutated in juvenile nephronophthisis type 4 encodes a novel protein that interacts with nephrocystin. Nat Genet 32(2):300-305. https://doi.org/10.1038/ng996

104. Schuermann MJ, Otto E, Becker A, Saar K, Ruschendorf F, Polak BC, Ala-Mello S, Hoefele J, Wiedensohler A, Haller M, Omran $\mathrm{H}$, Nurnberg P, Hildebrandt F (2002) Mapping of gene loci for nephronophthisis type 4 and senior-Loken syndrome, to chromosome 1p36. Am J Hum Genet 70(5):1240-1246. https://doi.org/ $10.1086 / 340317$

105. Monda JK, Cheeseman IM (2018) The kinetochore-microtubule interface at a glance. J Cell Sci. https://doi.org/10.1242/jcs. 214577

106. Musacchio A, Desai A (2017) A molecular view of kinetochore assembly and function. Biology (Basel). https://doi.org/10.3390/ biology6010005

107. Musacchio A, Salmon ED (2007) The spindle-assembly checkpoint in space and time. Nat Rev Mol Cell Bio 8(5):379-393. https://doi.org/10.1038/nrm2163

108. Hara M, Fukagawa T (2018) Kinetochore assembly and disassembly during mitotic entry and exit. Curr Opin Cell Biol 52:7381. https://doi.org/10.1016/j.ceb.2018.02.005

109. Hinshaw SM, Harrison SC (2018) Kinetochore function from the bottom up. Trends Cell Biol 28(1):22-33. https://doi.org/10. 1016/j.tcb.2017.09.002

110. Shrestha RL, Draviam VM (2013) Lateral to end-on conversion of chromosome-microtubule attachment requires kinesins CENPE and MCAK. Curr Biol 23(16):1514-1526. https://doi.org/10. 1016/j.cub.2013.06.040

111. Vergnolle MA, Taylor SS (2007) Cenp-F links kinetochores to Ndel1/Nde1/Lis1/dynein microtubule motor complexes. Curr 
Biol 17(13):1173-1179. https://doi.org/10.1016/j.cub.2007.05. 077

112. McEwen BF, Chan GK, Zubrowski B, Savoian MS, Sauer MT, Yen TJ (2001) CENP-E is essential for reliable bioriented spindle attachment, but chromosome alignment can be achieved via redundant mechanisms in mammalian cells. Mol Biol Cell 12(9):2776-2789. https://doi.org/10.1091/mbc.12.9.2776

113. Goshima G, Nedelec F, Vale RD (2005) Mechanisms for focusing mitotic spindle poles by minus end-directed motor proteins. J Cell Biol 171(2):229-240. https://doi.org/10.1083/jcb.20050 5107

114. Zhang G, Lischetti T, Hayward DG, Nilsson J (2015) Distinct domains in Bub1 localize RZZ and BubR1 to kinetochores to regulate the checkpoint. Nat Commun 6:7162. https://doi.org/ 10.1038/ncomms8162

115. Rieder CL, Cole RW, Khodjakov A, Sluder G (1995) The checkpoint delaying anaphase in response to chromosome monoorientation is mediated by an inhibitory signal produced by unattached kinetochores. J Cell Biol 130(4):941-948. https://doi.org/ 10.1083/jcb.130.4.941

116. Cheeseman IM, Chappie JS, Wilson-Kubalek EM, Desai A (2006) The conserved KMN network constitutes the core microtubule-binding site of the kinetochore. Cell 127(5):983-997. https://doi.org/10.1016/j.cell.2006.09.039

117. Volkov VA, Grissom PM, Arzhanik VK, Zaytsev AV, Renganathan K, McClure-Begley T, Old WM, Ahn N, McIntosh JR (2015) Centromere protein F includes two sites that couple efficiently to depolymerizing microtubules. J Cell Biol 209(6):813828. https://doi.org/10.1083/jcb.201408083

118. Waters AM, Asfahani R, Carroll P, Bicknell L, Lescai F, Bright A, Chanudet E, Brooks A, Christou-Savina S, Osman G, Walsh P, Bacchelli C, Chapgier A, Vernay B, Bader DM, Deshpande C, O'Sullivan M, Ocaka L, Stanescu H, Stewart HS, Hildebrandt F, Otto E, Johnson CA, Szymanska K, Katsanis N, Davis E, Kleta R, Hubank M, Doxsey S, Jackson A, Stupka E, Winey M, Beales PL (2015) The kinetochore protein, CENPF, is mutated in human ciliopathy and microcephaly phenotypes. J Med Genet 52(3):147-156. https://doi.org/10.1136/jmedgenet-2014-102691

119. Ito A, Goshima $G$ (2015) Microcephaly protein asp focuses the minus ends of spindle microtubules at the pole and within the spindle. J Cell Biol 211(5):999-1009. https://doi.org/10.1083/ jcb.201507001

120. Hampshire DJ, Ayub M, Springell K, Roberts E, Jafri H, Rashid Y, Bond J, Riley JH, Woods CG (2006) MORM syndrome (mental retardation, truncal obesity, retinal dystrophy and micropenis), a new autosomal recessive disorder, links to 9q34. Eur J Hum Genet 14(5):543-548. https://doi.org/10. 1038/sj.ejhg. 5201577

121. Sillje HH, Nagel S, Korner R, Nigg EA (2006) HURP is a ranimportin beta-regulated protein that stabilizes kinetochore microtubules in the vicinity of chromosomes. Curr Biol 16(8):731742. https://doi.org/10.1016/j.cub.2006.02.070

122. Booth DG, Hood FE, Prior IA, Royle SJ (2011) A TACC3/chTOG/clathrin complex stabilises kinetochore fibres by intermicrotubule bridging. EMBO J 30(5):906-919. https://doi.org/ 10.1038/emboj.2011.15

123. Nixon FM, Honnor TR, Clarke NI, Starling GP, Beckett AJ, Johansen AM, Brettschneider JA, Prior IA, Royle SJ (2017) Microtubule organization within mitotic spindles revealed by serial block face scanning electron microscopy and image analysis. J Cell Sci 130(10):1845-1855. https://doi.org/10.1242/jcs. 203877

124. Winey M, Goetsch L, Baum P, Byers B (1991) MPS1 and MPS2: novel yeast genes defining distinct steps of spindle pole body duplication. J Cell Biol 114(4):745-754. https://doi.org/10.1083/ jcb.114.4.745
125. Abrieu A, Magnaghi-Jaulin L, Kahana JA, Peter M, Castro A, Vigneron S, Lorca T, Cleveland DW, Labbe JC (2001) Mps1 is a kinetochore-associated kinase essential for the vertebrate mitotic checkpoint. Cell 106(1):83-93. https://doi.org/10.1016/ s0092-8674(01)00410-x

126. Majumder S, Fisk HA (2013) VDAC3 and Mps1 negatively regulate ciliogenesis. Cell Cycle 12(5):849-858. https://doi.org/10. $4161 /$ cc. 23824

127. Majumder S, Fisk HA (2014) Quantitative immunofluorescence assay to measure the variation in protein levels at centrosomes. J Vis Exp 94:52030. https://doi.org/10.3791/52030

128. Scholey JM (2003) Intraflagellar transport. Annu Rev Cell Dev Biol 19:423-443. https://doi.org/10.1146/annurev.cellbio.19. 111401.091318

129. Pedersen LB, Geimer S, Sloboda RD, Rosenbaum JL (2003) The microtubule plus end-tracking protein EB1 is localized to the flagellar tip and basal bodies in Chlamydomonas reinhardtii. Curr Biol 13(22):1969-1974. https://doi.org/10.1016/j.cub.2003.10. 058

130. Pan J, Wang Q, Snell WJ (2005) Cilium-generated signaling and cilia-related disorders. Lab Invest 85(4):452-463. https://doi.org/ 10.1038/labinvest.3700253

131. Schroder JM, Larsen J, Komarova Y, Akhmanova A, Thorsteinsson RI, Grigoriev I, Manguso R, Christensen ST, Pedersen SF, Geimer S, Pedersen LB (2011) EB1 and EB3 promote cilia biogenesis by several centrosome-related mechanisms. J Cell Sci 124(Pt 15):2539-2551. https://doi.org/10.1242/jcs.085852

132. Akhmanova A, Steinmetz MO (2010) Microtubule +TIPs at a glance. J Cell Sci 123(Pt 20):3415-3419. https://doi.org/10.1242/ jcs.062414

133. Tirnauer JS, Canman JC, Salmon ED, Mitchison TJ (2002) EB1 targets to kinetochores with attached, polymerizing microtubules. Mol Biol Cell 13(12):4308-4316. https://doi.org/10.1091/mbc. E02-04-0236

134. Mimori-Kiyosue Y, Grigoriev I, Lansbergen G, Sasaki H, Matsui C, Severin F, Galjart N, Grosveld F, Vorobjev I, Tsukita S, Akhmanova A (2005) CLASP1 and CLASP2 bind to EB1 and regulate microtubule plus-end dynamics at the cell cortex. J Cell Biol 168(1):141-153. https://doi.org/10.1083/jcb.200405094

135. Akhmanova A, Hoogenraad CC, Drabek K, Stepanova T, Dortland B, Verkerk T, Vermeulen W, Burgering BM, De Zeeuw CI, Grosveld F, Galjart N (2001) Clasps are CLIP-115 and -170 associating proteins involved in the regional regulation of microtubule dynamics in motile fibroblasts. Cell 104(6):923-935. https:// doi.org/10.1016/s0092-8674(01)00288-4

136. Das A, Dickinson DJ, Wood CC, Goldstein B, Slep KC (2015) Crescerin uses a TOG domain array to regulate microtubules in the primary cilium. Mol Biol Cell 26(23):4248-4264. https://doi. org/10.1091/mbc.E15-08-0603

137. Latour BL, Van De Weghe JC, Rusterholz TD, Letteboer SJ, Gomez A, Shaheen R, Gesemann M, Karamzade A, Asadollahi M, Barroso-Gil M, Chitre M, Grout ME, van Reeuwijk J, van Beersum SE, Miller CV, Dempsey JC, Morsy H, Bamshad MJ, Nickerson DA, Neuhauss SC, Boldt K, Ueffing M, Keramatipour M, Sayer JA, Alkuraya FS, Bachmann-Gagescu R, Roepman R, Doherty D (2020) Dysfunction of the ciliary ARMC9/TOGARAM1 protein module causes Joubert syndrome. J Clin Invest 130(8):4423-4439. https://doi.org/10.1172/JCI131656

138. Testa JR, Zhou JY, Bell DW, Yen TJ (1994) Chromosomal localization of the genes encoding the kinetochore proteins CENPE and CENPF to human chromosomes 4q24->q25 and $1 \mathrm{q} 32->$ q41, respectively, by fluorescence in situ hybridization. Genomics 23(3):691-693. https://doi.org/10.1006/geno.1994. 1558

139. Cooke CA, Schaar B, Yen TJ, Earnshaw WC (1997) Localization of CENP-E in the fibrous corona and outer plate of mammalian 
kinetochores from prometaphase through anaphase. Chromosoma 106(7):446-455. https://doi.org/10.1007/s004120050266

140. Yao X, Anderson KL, Cleveland DW (1997) The microtubuledependent motor centromere-associated protein E (CENP-E) is an integral component of kinetochore corona fibers that link centromeres to spindle microtubules. J Cell Biol 139(2):435-447. https://doi.org/10.1083/jcb.139.2.435

141. Itoh G, Ikeda M, Iemura K, Amin MA, Kuriyama S, Tanaka M, Mizuno N, Osakada H, Haraguchi T, Tanaka K (2018) Lateral attachment of kinetochores to microtubules is enriched in prometaphase rosette and facilitates chromosome alignment and bi-orientation establishment. Sci Rep 8(1):3888. https://doi.org/ 10.1038/s41598-018-22164-5

142. Yang X, Matsuda K, Bialek P, Jacquot S, Masuoka HC, Schinke T, Li L, Brancorsini S, Sassone-Corsi P, Townes TM, Hanauer A, Karsenty G (2004) ATF4 is a substrate of RSK2 and an essential regulator of osteoblast biology; implication for Coffin-Lowry syndrome. Cell 117(3):387-398. https://doi.org/10.1016/s00928674(04)00344-7

143. Chen A, Muzzio IA, Malleret G, Bartsch D, Verbitsky M, Pavlidis P, Yonan AL, Vronskaya S, Grody MB, Cepeda I, Gilliam TC, Kandel ER (2003) Inducible enhancement of memory storage and synaptic plasticity in transgenic mice expressing an inhibitor of ATF4 (CREB-2) and C/EBP proteins. Neuron 39(4):655-669. https://doi.org/10.1016/s0896-6273(03)00501-4

144. Yang TT, Su J, Wang WJ, Craige B, Witman GB, Tsou MF, Liao JC (2015) Superresolution pattern recognition reveals the architectural map of the ciliary transition zone. Sci Rep 5:14096. https://doi.org/10.1038/srep14096

145. Askham JM, Vaughan KT, Goodson HV, Morrison EE (2002) Evidence that an interaction between EB1 and p150(Glued) is required for the formation and maintenance of a radial microtubule array anchored at the centrosome. Mol Biol Cell 13(10):3627-3645. https://doi.org/10.1091/mbc.e02-01-0061

146. Lam C, Vergnolle MA, Thorpe L, Woodman PG, Allan VJ (2010) Functional interplay between LIS1, NDE1 and NDEL1 in dynein-dependent organelle positioning. J Cell Sci 123(Pt 2):202-212. https://doi.org/10.1242/jcs.059337

147. Kim S, Zaghloul NA, Bubenshchikova E, Oh EC, Rankin S, Katsanis N, Obara T, Tsiokas L (2011) Nde1-mediated inhibition of ciliogenesis affects cell cycle re-entry. Nat Cell Biol 13(4):351360. https://doi.org/10.1038/ncb2183

148. Shmueli A, Segal M, Sapir T, Tsutsumi R, Noritake J, Bar A, Sapoznik S, Fukata Y, Orr I, Fukata M, Reiner O (2010) Ndel1 palmitoylation: a new mean to regulate cytoplasmic dynein activity. EMBO J 29(1):107-119. https://doi.org/10.1038/emboj.2009. 325

149. Alkuraya FS, Cai X, Emery C, Mochida GH, Al-Dosari MS, Felie JM, Hill RS, Barry BJ, Partlow JN, Gascon GG, Kentab A, Jan M, Shaheen R, Feng Y, Walsh CA (2011) Human mutations in NDE1 cause extreme microcephaly with lissencephaly (corrected). Am J Hum Genet 88(5):536-547. https://doi.org/10. 1016/j.ajhg.2011.04.003

150. Bond J, Roberts E, Springell K, Lizarraga SB, Scott S, Higgins J, Hampshire DJ, Morrison EE, Leal GF, Silva EO, Costa SM, Baralle D, Raponi M, Karbani G, Rashid Y, Jafri H, Bennett C, Corry P, Walsh CA, Woods CG (2005) A centrosomal mechanism involving CDK5RAP2 and CENPJ controls brain size. Nat Genet 37(4):353-355. https://doi.org/10.1038/ng1539

151. Maskey D, Marlin MC, Kim S, Kim S, Ong EC, Li G, Tsiokas L (2015) Cell cycle-dependent ubiquitylation and destruction of NDE1 by CDK5-FBW7 regulates ciliary length. EMBO J 34(19):2424-2440. https://doi.org/10.15252/embj.201490831

152. Magen D, Ofir A, Berger L, Goldsher D, Eran A, Katib N, Nijem Y, Vlodavsky E, Tzur S, Behar DM, Fellig Y, Mandel H (2015) Autosomal recessive lissencephaly with cerebellar hypoplasia is associated with a loss-of-function mutation in CDK5. Hum Genet 134(3):305-314. https://doi.org/10.1007/s00439-014-1522-5

153. Hirasawa M, Ohshima T, Takahashi S, Longenecker G, Honjo Y, Veeranna PHC, Mikoshiba K, Brady RO, Kulkarni AB (2004) Perinatal abrogation of $\mathrm{Cdk} 5$ expression in brain results in neuronal migration defects. Proc Natl Acad Sci USA 101(16):62496254. https://doi.org/10.1073/pnas.0307322101

154. Feng Y, Walsh CA (2004) Mitotic spindle regulation by Nde1 controls cerebral cortical size. Neuron 44(2):279-293. https:// doi.org/10.1016/j.neuron.2004.09.023

155. Cardoso C, Leventer RJ, Dowling JJ, Ward HL, Chung J, Petras KS, Roseberry JA, Weiss AM, Das S, Martin CL, Pilz DT, Dobyns WB, Ledbetter DH (2002) Clinical and molecular basis of classical lissencephaly: mutations in the LIS1 gene (PAFAH1B1). Hum Mutat 19(1):4-15. https://doi.org/10.1002/ humu. 10028

156. Pedersen LB, Rompolas P, Christensen ST, Rosenbaum JL, King SM (2007) The lissencephaly protein Lis1 is present in motile mammalian cilia and requires outer arm dynein for targeting to Chlamydomonas flagella. J Cell Sci 120(Pt 5):858-867. https:// doi.org/10.1242/jcs.03374

157. Ludington WB, Wemmer KA, Lechtreck KF, Witman GB, Marshall WF (2013) Avalanche-like behavior in ciliary import. Proc Natl Acad Sci USA 110(10):3925-3930. https://doi.org/10.1073/ pnas. 1217354110

158. Maiuri T, Woloshansky T, Xia J, Truant R (2013) The huntingtin N17 domain is a multifunctional CRM1 and ran-dependent nuclear and cilial export signal. Hum Mol Genet 22(7):13831394. https://doi.org/10.1093/hmg/dds554

159. Fan S, Margolis B (2011) The ran importin system in cilia trafficking. Organogenesis 7(3):147-153. https://doi.org/10.4161/ org.7.3.17084

160. Takao D, Verhey KJ (2016) Gated entry into the ciliary compartment. Cell Mol Life Sci 73(1):119-127. https://doi.org/10.1007/ s00018-015-2058-0

161. Cho KI, Haque M, Wang J, Yu M, Hao Y, Qiu S, Pillai IC, Peachey NS, Ferreira PA (2013) Distinct and atypical intrinsic and extrinsic cell death pathways between photoreceptor cell types upon specific ablation of Ranbp2 in cone photoreceptors. PLoS Genet 9(6):e1003555. https://doi.org/10.1371/journal. pgen.1003555

162. Jia L, Li B, Yu H (2016) The Bub1-Plk1 kinase complex promotes spindle checkpoint signalling through Cdc20 phosphorylation. Nat Commun 7:10818. https://doi.org/10.1038/ncomm s10818

163. Hutterer A, Berdnik D, Wirtz-Peitz F, Zigman M, Schleiffer A, Knoblich JA (2006) Mitotic activation of the kinase auroraA requires its binding partner Bora. Dev Cell 11(2):147-157. https://doi.org/10.1016/j.devcel.2006.06.002

164. Wang R, Song Y, Liu X, Wang Q, Wang Y, Li L, Kang C, Zhang Q (2017) UBE2C induces EMT through Wnt/betacatenin and PI3K/Akt signaling pathways by regulating phosphorylation levels of aurora-A. Int J Oncol 50(4):1116-1126. https://doi.org/10. 3892/ijo.2017.3880

165. Zhang C, Qu L, Lian S, Meng L, Min L, Liu J, Song Q, Shen L, Shou C (2019) PRL-3 promotes ubiquitination and degradation of AURKA and colorectal cancer progression via dephosphorylation of FZR1. Cancer Res 79(5):928-940. https://doi.org/10. 1158/0008-5472.CAN-18-0520

166. Reiter JF, Leroux MR (2017) Genes and molecular pathways underpinning ciliopathies. Nat Rev Mol Cell Biol 18(9):533-547. https://doi.org/10.1038/nrm.2017.60

167. Pan J, Snell W (2007) The primary cilium: keeper of the key to cell division. Cell 129(7):1255-1257. https://doi.org/10.1016/j. cell.2007.06.018 
168. Wang L, Dynlacht BD (2018) The regulation of cilium assembly and disassembly in development and disease. Development 145 (18):dev151407. doi: https://doi.org/10.1242/dev.151407

169. Ran J, Yang YF, Li DW, Liu M, Zhou J (2015) Deacetylation of alpha-tubulin and cortactin is required for HDAC6 to trigger ciliary disassembly. Sci Rep 5:12917. https://doi.org/10.1038/ srep12917

170. Huang KY, Diener DR, Rosenbaum JL (2009) The ubiquitin conjugation system is involved in the disassembly of cilia and flagella. J Cell Biol 186(4):601-613. https://doi.org/10.1083/jcb. 200903066

171. Hossain D, Tsang WY (2019) The role of ubiquitination in the regulation of primary cilia assembly and disassembly. Semin Cell Dev Biol 93:145-152. https://doi.org/10.1016/j.semcdb.2018.09. 005
172. Hershko A, Ciechanover A (1998) The ubiquitin system. Annu Rev Biochem 67:425-479. https://doi.org/10.1146/annurev.bioch em.67.1.425

173. Glotzer M, Murray AW, Kirschner MW (1991) Cyclin is degraded by the ubiquitin pathway. Nature 349(6305):132-138. https://doi.org/10.1038/349132a0

174. Sanchez AD, Feldman JL (2017) Microtubule-organizing centers: from the centrosome to non-centrosomal sites. Curr Opin Cell Biol 44:93-101. https://doi.org/10.1016/j.ceb.2016.09.003

Publisher's Note Springer Nature remains neutral with regard to jurisdictional claims in published maps and institutional affiliations. 